OPEN ACCESS

Edited by:

Vineet Kumar,

National Environmental Engineering

Research Institute (CSIR), India

Reviewed by:

Touseef Hussain,

Aligarh Muslim University, India

Renu Solanki,

University of Delhi, India

*Correspondence:

Raunak Dhanker

raunakbiotech@gmail.com

Specialty section:

This article was submitted to

Microbiotechnology,

a section of the journal

Frontiers in Microbiology

Received: 24 October 2021 Accepted: 21 December 2021

Published: 03 February 2022

Citation:

Mathew MM, Khatana K, Vats V, Dhanker R, Kumar R, Dahms H-U and

Hwang J-S (2022) Biological

Approaches Integrating Algae and Bacteria for the Degradation of Wastewater Contaminants $-A$ Review. Front. Microbiol. 12:801051. doi: 10.3389/fmicb.2021.801051

\section{Biological Approaches Integrating Algae and Bacteria for the Degradation of Wastewater Contaminants-A Review}

\author{
Merwin Mammen Mathew ${ }^{1}$, Kanchan Khatana ${ }^{1}$, Vaidehi Vats ${ }^{1}$, Raunak Dhanker ${ }^{1 *}$, \\ Ram Kumar'2, Hans-Uwe Dahms ${ }^{3}$ and Jiang-Shiou Hwang ${ }^{4,5,6}$
}

'Department of Basic and Applied Sciences, School of Engineering Sciences, GD Goenka University, Gurugram, India, ${ }^{2}$ Ecosystem Research Laboratory, Department of Environmental Science, School of Earth, Biological and Environmental Sciences, Central University of South Bihar, Fatehpur, India, ${ }^{3}$ Department of Biomedical Science and Environmental Biology, Kaohsiung Medical University, Kaohsiung, Taiwan, ${ }^{4}$ Institute of Marine Biology, National Taiwan Ocean University, Keelung, Taiwan, ${ }^{5}$ Center of Excellence for Ocean Engineering, National Taiwan Ocean University, Keelung, Taiwan, ${ }^{6}$ Center of Excellence for the Oceans, National Taiwan Ocean University, Keelung, Taiwan

The traditional approach for biodegradation of organic matter in sewage treatment used a consortium of bacterial spp. that produce untreated or partially treated inorganic contaminants resulting in large amounts of poor-quality sludge. The aeration process of activated sludge treatment requires high energy. So, a sustainable technique for sewage treatment that could produce less amount of sludge and less energy demanding is required for various developed and developing countries. This led to research into using microalgae for wastewater treatment as they reduce concentrations of nutrients like inorganic nitrates and phosphates from the sewage water, hence reducing the associated chemical oxygen demand (COD). The presence of microalgae removes nutrient concentration in water resulting in reduction of chemical oxygen demand (COD) and toxic heavy metals like $\mathrm{Al}, \mathrm{Ni}$, and $\mathrm{Cu}$. Their growth also offers opportunity to produce biofuels and bioproducts from algal biomass. To optimize use of microalgae, technologies like high-rate algal ponds (HRAPs) have been developed, that typically use $22 \%$ of the electricity used in Sequencing Batch Reactors for activated sludge treatment with added economic and environmental benefits like reduced comparative operation cost per cubic meter, mitigate global warming, and eutrophication potentials. The addition of suitable bacterial species may further enhance the treatment potential in the wastewater medium as the inorganic nutrients are assimilated into the algal biomass, while the organic nutrients are utilized by bacteria. Further, the mutual exchange of $\mathrm{CO}_{2}$ and $\mathrm{O}_{2}$ between the algae and the bacteria helps in enhancing the photosynthetic activity of algae and oxidation by bacteria leading to a higher overall nutrient removal efficiency. Even negative interactions between algae and bacteria mediated by various secondary metabolites (phycotoxins) have proven beneficial as it controls the algal bloom in the eutrophic water bodies. Herein, we attempt to review various opportunities and limitations of using a combination of microalgae and bacteria in wastewater treatment method toward cost effective, eco-friendly, and sustainable method of sewage treatment.

Keywords: microalgae, bacteria, wastewater treatment, integrated approach, sustainable method 


\section{INTRODUCTION}

Bacteria and algae are extensively used in the treatment of wastewater (Almomani et al., 2019). The parameters that influence the growth of microbes are firstly geographical location, secondly the type of pond in which bacteria will be grown, thirdly the characteristics of the wastewater entering the plant, and finally the operating parameters of the system, such as aeration, agitation, and chemical injection. All of these factors make quantitative changes between autotrophic and heterotrophic bacteria (Marcin et al., 2018). Gram-negative bacteria of the proteobacteria type are a predominant group of bacteria of which Betaproteobacteria is the most abundant class which is largely responsible for the elimination of organic elements and nutrients. The other branches are Bacteroidetes, Acidobacteria, and Chloroflexi. The most numerous types of bacteria are Tetrasphaera, Trichococcus, Candidatus Microthrix, Rhodoferax, Rhodobacter, and Hyphomicrobium that are useful for the degradation of microbes (Gunther et al., 2020).

Microalgae culture offers an economically viable and ecofriendly method for wastewater treatment, because they provide a tertiary biotreatment coupled with the production of valuable biomass, which can be used for several purposes (Alexandre et al., 2018; Gudiukaite et al., 2021). Microalgae cultures offer an elegant solution to tertiary and quaternary treatments due to the ability of microalgae to use inorganic nitrogen and phosphorus for their growth. They are also known for their capacity to remove heavy metals and some toxic organic compounds, thus can also help to prevent secondary pollution (Raouf et al., 2012; Arora et al., 2021; Dhanker et al., 2021).

Microalgae and bacteria are used to recover nutrients from wastewater as alternative to conventional technologies such as those based on activated sludge. Since no sterile conditions are possible in wastewater systems, the naturally occurring bacterial consortium prevails in the reactors and its occurrence is a function of the wastewater composition, environmental conditions, reactor design, and operation conditions (Muñoz and Guieysse, 2006). Bacteria utilize the organic wastes present and produce $\mathrm{CO}_{2}$ as a by-product. The microalgae in turn utilize this $\mathrm{CO}_{2}$ to produce carbohydrates and $\mathrm{O}_{2}$ through photosynthesis, of which the former is needed for biomass production, while the latter serves as the terminal electron acceptor for aerobic respiration in bacteria. According to this scheme, a "natural" equilibrium is established between microalgae and bacteria based on the conditions of the reactor. However, the composition of the consortium in this equilibrium can differ widely depending on the conditions prevailing in the

Abbreviations: NADPH, nicotinamide adenine dinucleotide phosphate(reduced); ATP, adenosine triphosphate; PMF, proton motive force; PAR, photosynthetically active radiation; GOGAT, glutamine oxoglutarate aminotransferase; NADP, nicotinamide adenine dinucleotide phosphate; DNA, deoxyribonucleic acid; RNA, ribonucleic acid; ADP, Adenosine diphosphate; TCA, tricarboxylic acid cycle; Eutrophication, when water body becomes excessively enriched with nutrients; TP, total phosphorus; TN, total nitrogen; PSW, poultry slaughterhouse water; STE, secondary treatment effluent; UWTD, urban wastewater treatment directive; HRT, hydraulic retention Time; PBR, photobioreactor. reactor. The consortium composition directly affects the ratios between the various phenomena like oxygen production, $\mathrm{CO}_{2}$ consumption, nitrogen, and phosphorus assimilation. Therefore, the levels of these processes keep changing alongside the change in consortia (Molazadeh et al., 2019). Wastewater treatment efficiency of microorganisms can be improved by eliminating the fats and oils responsible for the habitat degradation by manipulating the presence of appropriate bacterial species for the treatment of cold or hot water (Zahara et al., 2020).

This paper begins with a succinct discussion on the need of wastewater treatment and then presents a glimpse into the current trends in the independent use of bacteria and microalgae for wastewater treatment, and finally explains the integrated application of microalgae and heterotrophic bacteria for eco-friendly sewage treatment process based on researches done in the area.

\section{RELEVANCE OF WASTEWATER TREATMENT IN CURRENT SCENARIO}

The modern-day aerobic sewage treatment plants make use of natural air currents. This process eliminates the organic pollutants and their associated odor by providing conditions for their complete oxidation into carbon dioxide, nitrogen, and water. The treated effluent is thus pollutant free and can be discharged for use (Marina et al., 2019). Water treatment facilities are designed to speed up the natural process of purifying water. With billions of people, the natural process is overloaded. Without proper wastewater treatment, the amount of wastewater would cause devastation, as it still does today in developing countries. Globally, over $80 \%$ of all wastewater is discharged without treatment. Countries having water treatment facilities use various methods to treat wastewater with one common goal, i.e., purify water as much as possible and send it back into the environment to keep humans and the Earth safe and thriving (Holger et al., 2006; Molazadeh et al., 2019).

Wastewater contains elements which are toxic to humans and the ecosystem. Wastewater treatment facilities help to purify the water and improve the situations like what is currently seen in developing countries (Bjorn et al., 2006; Desai et al., 2021). Untreated water poses significant health risks, accounting for 1.7 million deaths annually, of which over $90 \%$ are in developing countries. Several water-related diseases, including cholera and schistosomiasis, remain widespread across many developing countries, where only a very small fraction of domestic and urban wastewater is treated prior to its release into the environment (Richard, 2019). Presence of heavy metal in water results in severe health issues including cardiovascular disorders, neuronal damage, renal injuries, and risk of cancer and diabetes (Jaishankar et al., 2014). While Mother Nature does her best to naturally process wastewater, there is too much for her to handle. The amount of wastewater is increasing day by day in tune with the global population increase (Chia et al., 2007; Cristine et al., 2011). 


\section{Ways to treat Wastewater}

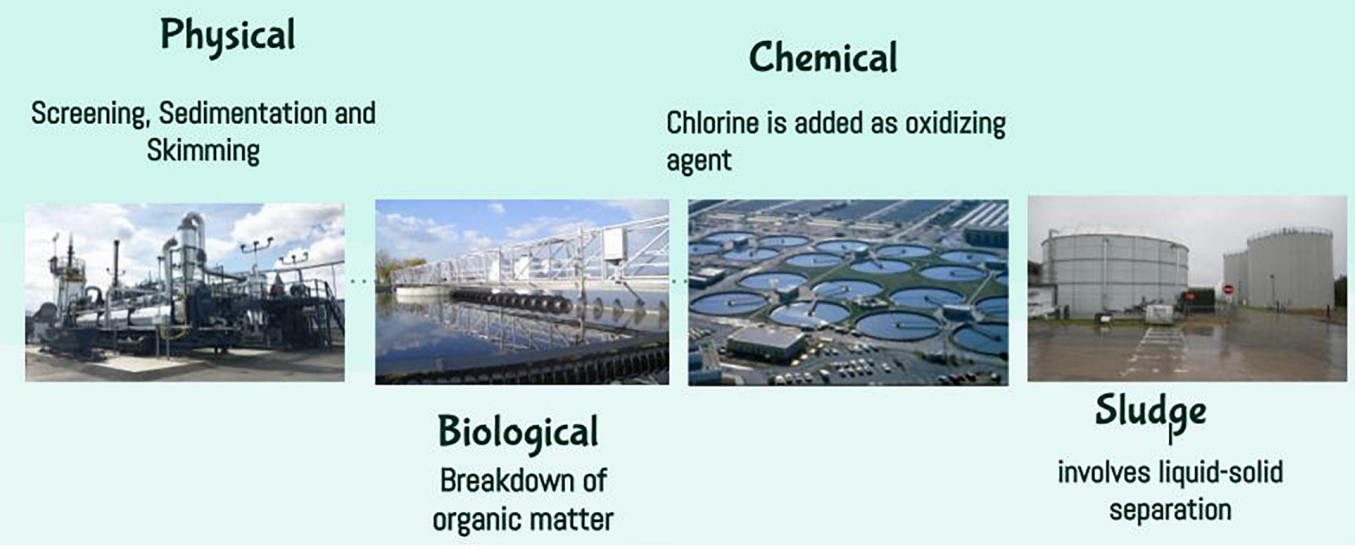

FIGURE 1 | Ways to treat wastewater.

\section{CURRENT WASTEWATER TREATMENT}

Four common ways to treat wastewater include physical water treatment, biological water treatment, chemical treatment, and sludge treatment (Figure 1).

\section{Physical (Conventional) Water Treatment}

Processes like screening, sedimentation, and skimming are used to remove the solids. No chemicals are involved in this process. One of the main techniques of physical wastewater treatment includes sedimentation, i.e., a process of suspending the insoluble or heavy particles from the wastewater. Separation of pure water can be done when the insoluble material settles down at the bottom (Mathew and Alan, 2009). Another effective physical water treatment technique includes aeration. This process consists of circulating air through the water to provide oxygen to it. Filtration, the third method, is used for filtering out all the contaminants. Special custom designed filters are used to separate the contaminants and insoluble particles by passing the wastewater through the filter. The sand filter is the most commonly used filter. The grease found on the surface of some wastewater can also be removed easily through this method (Harleman and Murcott, 1999).

\section{Biological Water Treatment}

This uses various biological processes to break down the organic matter present in wastewater, such as soap, human waste, oils, and food. Microorganisms metabolize organic matter in the wastewater in biological treatment. It can be divided into three categories: (a) aerobic processes: bacteria decompose organic matter by using oxygen as the oxidizing agent, leading to its conversion to carbon dioxide that can then be used by plants; (b) anaerobic processes: here, fermentation is used for fermenting the waste at a specific temperature. Oxygen is not used in anaerobic process, and (c) composting: a type of aerobic process where wastewater is treated by mixing it with sawdust or other carbon sources (Yuansong et al., 2003; Arun, 2011).

\section{Chemical Water Treatment}

This treatment involves the application of chemicals in water. Chlorine, an oxidizing chemical, is commonly used to kill bacteria which decomposes water by adding contaminants to it (Jari et al., 2003). Another oxidizing agent used for purifying the wastewater is ozone. Neutralization is a technique where an acid or base is added to bring the water to its natural $\mathrm{pH}$ of 7 . Chemicals prevent the bacteria from reproducing in water, thus making the water pure (Ødegaard and Karlsson, 1994).

\section{Sludge Treatment}

This is a solid-liquid separation process where the least possible residual moisture is required in the solid phase and the lowest possible solid particle residues are required in the separated liquid phase (Tong et al., 1980; Krist et al., 2004).

\section{THE ROLE OF BACTERIA AND MICROALGAE IN WASTEWATER TREATMENT}

\section{Microalgal Treatment}

Microalgae include prokaryotic cyanobacteria and eukaryotic autotrophic protist-algae that are too small to be seen without a microscope (Larsdotter, 2006). Microalgae are primary producers of any aquatic ecosystem which are the main food of secondary producers (Dhanker et al., 2012, 2013). Algal cultures are being used for the treatment of wastewater from last 75 years, 
and today the biologists in United States, Thailand, Taiwan, and Mexico are taking substantial interest in this area due to their understanding of the biology, ecology, and engineering of large-scale algal culture systems (Raouf et al., 2012). Many factors like fear of food insecurity, rise of property cost, and consciousness toward the need for environmental protection have greatly promoted the development of microalgal water treatment systems (Paddock, 2019).

Microalgae purify water through either direct uptake of contaminants or their transformation to harmless products (Dhanker et al., 2021). Algal species are reported to facilitate bacterial degradation of organics by providing oxygen through photosynthesis, which reduces costs and energy expenditure associated with the gassing/stirring process for aeration (Wollmann et al., 2019). Nitrogen, phosphorous, and carbonaceous substances are taken up by microalgae to build up their biomass. The nitrogen assimilated is in the form of ammonia, nitrate, and nitrite; at the same time, carbon dioxide removal is also possible as it is a photosynthetic substrate. Additionally, microalgae have potential to remove heavy metals from water (Ahmed et al., 2022) and may be utilized for production of biofuel source, due to a much higher per unit area yield than terrestrial oil seed crops (Wang et al., 2010; Gudiukaite et al., 2021).

The mode of $\mathrm{CO}_{2}$ fixation employed by microalgae is called oxygenic photosynthesis which transforms it to reduced carbon compounds like sugars in the presence of water and light (Benedetti et al., 2018). This process is mediated by four membrane protein complexes that are multi-subunit in nature, namely, photosystem 1 , photosystem 2 , cytochrome $b_{6} f$, and F-ATPase. These complexes are found on the thylakoid membranes of chloroplast and the equivalent structures of cyanobacteria and carry out the light dependent oxidation of water to oxygen, reduction of NADPH (nicotine adenine dinucleotide phosphate), and the synthesis of ATP (adenosine triphosphate). The two photosystems separately oxidize water and reduce NADPH, and the cytochrome transfers electrons between the photosystems while also generating the PMF (proton motive force) for ATP synthesis which in turn is the job of F-ATPase. In the dark, the stroma of the chloroplast acts as the site of the Calvin cycle that takes in $\mathrm{CO}_{2}$ (carbon source) from the environment and the ATP (energy source) and NADPH (reducing agent) from the light reaction to produce carbohydrates (Nelson and Shem, 2004). The photosynthetically active radiation (PAR) ranges between 400 and $700 \mathrm{~nm}$, and 8 such PAR photons of light at $550 \mathrm{~nm}$ are required for $\mathrm{CO}_{2}$ fixation or splitting of 2 water molecules to one molecule of diatomic oxygen. Practically, this becomes 10 photons as photosynthesis is not $100 \%$ efficient (Su, 2021). The relative $\mathrm{CO}_{2}$ fixation concentrations of different microalgae species were evaluated and found to be highest in Synechocystis aquatilis$1500 \mathrm{mg} / \mathrm{L} /$ day, Botryococcus braunii-1,100 mg/L/day, Chlorella vulgaris-865 mg/L/day, and in Synechococcus spp. Species that fixed higher $\mathrm{CO}_{2}$ concentrations were also found to generate higher biomass, in general (Singh and Singh, 2014).

Nitrogen is an essential component making up to $1-10 \%$ $(6-10 \%$ in case of Chlorella) of a cell's dry in the form of its building blocks like the genetic material, enzymes, proteins, vitamins, hormones, alkaloids, energy transfer molecules, and amides (Jia and Yuan, 2016). Ammonium $\left(\mathrm{NH}_{4}{ }^{+}\right)$is preferred as a nitrogen source in green algae as assimilation of other sources is partially or completely inhibited in its presence. It is assimilated by the help of the glutamine synthase (GS)glutamate synthase cycle. Glutamate synthase is also called glutamine oxoglutarate aminotransferase or GOGAT. Some green algae under certain conditions use the NADP-glutamate dehydrogenase (GDH) pathway for its assimilation. Algae like Tetraselmis striata have high levels of GS and GOGAT indicating its dominant role in nitrogen assimilation in them, over GDH whose levels are lower (Hellebust and Ahmad, 1989). Still at concentrations above $100 \mathrm{mg} / \mathrm{L}$, ammonium proves to be toxic to microalgae as it converts to ammonia that inhibits microalgal photosynthesis (Su, 2021). The other nitrogen sources being important for algal growth, generally present in natural waters with higher concentrations, are nitrate and nitrite. Their assimilation is dependent on the activity and capacity of nitrate and nitrite transport systems of cells, then the amount and activity of cellular nitrate and nitrite reductase. The genes of nitrate and nitrite reductase are repressed by the presence of ammonia, and for green algae grown on reduced nitrogen sources, presence of nitrate and absence of reduced nitrogen are essential for the induction of nitrate reductase. The final source is the organic nitrogen as in amino acids or urea. This source is variable from species to species as it is dependent on the differences in transport abilities and degradation enzymes. For instance, Stichococcus bacillaris possess systems for the active transport of multiple acidic, basic, and neutral amino acids, while some species of the order Volvocales have active transport systems for arginine but cannot transport other amino acids (Hellebust and Ahmad, 1989).

For heavy metal removal from water, microalgae employ the following three mechanisms, i.e., extracellular precipitation that needs living cells, cell surface sorption/complexation which can be done by both living or dead cells, and intracellular accumulation which brings in the need for metabolic processes of the microalgae. Microalgae species like Chlamydomonas reinhardtii contribute efficiently to the removal of Cadmium, and live cells of Planothidium lanceolatum take up large quantities of $\mathrm{Cd}^{2+}$ at $275.51 \mathrm{mg} / \mathrm{g}$. For Cobalt removal Spirogyra spp. and Oscillatoria angustissima prove to be promising. Chlorella and Spirulina spp. are good at removing hexavalent Chromium $\left(\mathrm{Cr}^{6+}\right)$ with Spirulina having a chromium uptake rate of $333 \mathrm{mg} / \mathrm{g}$. Spirulina species has been shown to remove copper at $389 \mathrm{mg} / \mathrm{g}$ along with nickel and zinc, both at $1,378 \mathrm{mg} / \mathrm{g}$. All these remediation activities take place under different ranges of pH (Kumar et al., 2015).

Phosphorus is used by microalgae to produce nucleic acidsDNA (deoxyribonucleic acid) and RNA (ribonucleic acid), ATP for energy, and phospholipids of the membrane. The most preferred forms for uptake are $\mathrm{PO}_{4}{ }^{3-}, \mathrm{HPO}_{4}{ }^{2-}, \mathrm{H}_{2} \mathrm{PO}_{4}{ }^{-}$of which the ones with lower charge have greater bioavailability, but polyphosphate is also available for use in microalgae. Phosphite $\left(\mathrm{PO}_{3}^{3-}\right)$ utilization has only been demonstrated in cyanobacteria. Inorganic phosphate is taken inside the cell via 
Pi transporters, while phosphatases on the membrane surface hydrolyze phosphate containing organic compounds and import the phosphate released. The phosphate assimilated in the cells is elongated upon to produce acid soluble polyphosphate (ASP) or acid insoluble polyphosphate (AISP) by polyphosphate kinase by the hydrolysis of ATP to ADP (adenosine diphosphate). High light intensity promotes formation of ASP and its conversion to proteins and DNA. The extracellular phosphorous compounds after internalization are converted to cellular phosphate that is used for synthesis of phospholipids and RNA, though the transfer of phosphate to RNA is inhibited by light. When excess phosphorus is found in the environment, or if the cell is transferred from a deficient to rich environment with respect to phosphorus, then it assimilates more phosphorus than what is needed for survival. This excess phosphate assimilated is largely transformed to AISP and stored in vacuoles for use in case of future phosphorus deprivation, by transfer to other algal phosphorus containing compounds for cell viability (Su, 2021). The microalgae C. vulgaris is commonly used for removal of N, P compounds and heavy metals from the wastewater during tertiary treatment (de-Bashan et al., 2002). The capacities of microalgae to remove nitrogen and phosphorus from different wastewater sources can be seen in Table $\mathbf{1}$, for example, Coelastrum microporum that removes 88 and $89 \%$ of the total nitrogen and phosphorus contents, respectively.

Many microalgae species exhibit a mixotrophic mode of nutrition based on light conditions, due to which they can switch between auto and heterotrophy. This allows them to use organic carbon as biomass, which then contributes to greater biomass removal during wastewater treatment. Still, they lack a proper organic carbon uptake mechanism and transport pathway due to which only a few of them can grow heterotrophically like C. reinhardtii. Organic carbon sources are limited to sugars (galactose, glucose, to some extent fructose), alcohols (glycerol and ethanol), and acids (acetic acid). Glucose is metabolized via the Embden Meyerhof Pathway (EMP) under lighted conditions or by pentose phosphate pathway (PPP) in the dark heterotrophically. The resulting pyruvate forms acetyl CoA and undergoes the TCA (tricarboxylic acid) cycle under aerobic conditions ( $\mathrm{Su}, 2021)$.

\section{The Factors Affecting the Treatment of Wastewater by Microalgae}

The factors affecting the treatment of wastewater by microalgae which are often closely associated with their growth are:

(a) $\mathrm{CO}_{2}$ availability, which may reduce the developmental rate of algal biomass if found to be low. Hence, the rate of nutrient and heavy metal assimilation should also decrease. For optimum algal growth air enriched with $1-5 \% \mathrm{CO}_{2}$ may be provided as atmospheric $\mathrm{CO}_{2}$ levels are far below optimum at $0.033 \%$ (Larsdotter, 2006).

(b) High ammonium ion concentrations of water $(100 \mathrm{mg} / \mathrm{L})$ cause ammonia to form that inhibit the growth of algae at concentrations $>30 \mathrm{mg} / \mathrm{L}$ and $\mathrm{pH} 9$ (Park and Craggs, 2011), by obstructing the microalgal photosynthetic pathway (Su, 2021).

(c) The higher $\mathrm{pH}$ level reduces $\mathrm{CO}_{2}$ uptake, that interferes with the activity of the RuBisCO enzyme, and promotes the dissociation of $\mathrm{NH}_{4}{ }^{+}$to $\mathrm{NH}_{3}$ (Salces et al., 2019).

(d) $\mathrm{O}_{2}$ concentrations higher than $20 \mathrm{mg} / \mathrm{L}$ causes photorespiration and $\mathrm{O}_{2}$ radical formation resulting in partial inhibition of photosynthesis which together leads to decreased microalgal growth (de Godos et al., 2017).

(e) Temperature, which causes growth to increase up to a certain point, but which declines rapidly beyond this threshold (Larsdotter, 2006). Though temperature is strain dependent, its optimum generally lies between 20 and $30^{\circ} \mathrm{C}$ and maintaining cultures at these optimum

TABLE 1 | Showing effectiveness of different microalgal species at removing total nitrogen (TN) and total phosphorus (TP) from different wastewaters.

\begin{tabular}{|c|c|c|c|c|c|c|}
\hline Main microalgae & Wastewater used & $\begin{array}{c}\text { TN initial } \\
\text { concentration }(\mathrm{mg} / \mathrm{L})\end{array}$ & TN removed $(\%)$ & $\begin{array}{c}\text { TP initial } \\
\text { concentration }(\mathrm{mg} / \mathrm{L})\end{array}$ & TP removed $(\%)$ & References \\
\hline $\begin{array}{l}\text { Micractinium inermum } \\
\text { NLP-F014 }\end{array}$ & $\begin{array}{l}\text { Bold modified basal } \\
\text { freshwater (BMBF) } \\
\text { nutrient solution }\end{array}$ & $36 \pm 1.1$ & 95.69 & $49 \pm 0.71$ & 10.71 & $\begin{array}{l}\text { Jeong and Jang, } \\
2020\end{array}$ \\
\hline $\begin{array}{l}\text { Scenedesmus } \\
\text { dimorphus }\end{array}$ & $\begin{array}{l}\text { Dairy industry } \\
\text { wastewater }\end{array}$ & 36.3 & $>90$ & 112 & $20-55$ & Salces et al., 2019 \\
\hline Micractinium reisseri & Piggery wastewater & 53 & 7.547 & 7.1 & 2.817 & $\begin{array}{l}\text { Abou-Shanab } \\
\text { et al., } 2013\end{array}$ \\
\hline $\begin{array}{l}\text { Chlamydomonas sp. } \\
\text { (YG04) }\end{array}$ & $\begin{array}{l}\text { Municipal wastewater } \\
\text { secondary effluent }\end{array}$ & $190.7 \pm 0.12$ & 77.57 & $19.11 \pm 0.03$ & 100 & Amini et al., 2014 \\
\hline Nitzschia cf. pusilla & Piggery wastewater & 53 & 15.09 & 7.1 & 9.859 & $\begin{array}{l}\text { Abou-Shanab } \\
\text { et al., } 2013\end{array}$ \\
\hline $\begin{array}{l}\text { Coelastrum } \\
\text { microporum }\end{array}$ & Municipal wastewater & 40 & 88 & 5.3 & 89 & Salces et al., 2019 \\
\hline Chlorella zofingiensis & $\begin{array}{l}\text { Untreated and } \\
\text { undiluted pig anaerobic } \\
\text { digested effluent }\end{array}$ & $1011-1050$ & 82.7 & $25-26.5$ & 98.17 & Li et al., 2019 \\
\hline $\begin{array}{l}\text { Mucidosphaerium } \\
\text { pulchellum }\end{array}$ & Domestic wastewater & $64-79$ & 79 & $4.6-7.2$ & 49 & Salces et al., 2019 \\
\hline
\end{tabular}


temperature's leads to greater nutrient removal efficiencies (Salces et al., 2019).

(f) Light increases the growth of microalgae due to increasing photosynthesis rates up to a certain threshold after which it decreases photosynthetic rates (Park et al., 2011).

(g) Cynobacterial inhibitory substances reduce the growth of eukaryotic algae (Larsdotter, 2006).

(h) Presence of parasites and algae virus organisms, e.g., rotifers and protozoa, interferes with the rate at which algae treats wastewater and produces important by-products (Grobbelaar, 1982; Mostert and Grobbelaar, 1987).

(i) Presence of acetate which is toxic to some species as its un-ionized form can penetrate the cell membrane and enter inside and ionize there, thus causing internal damage (Larsdotter, 2006).

(j) High quantities of organic substances inhibit nutrient uptake by microalgae (Ogbonna et al., 2000).

\section{Wastewater Treatment Using High-Rate Algal Pond: A Microalgal Technology}

High-rate algal pond (HRAP) is a technology developed in the 1950s that uses microalgae for resource recovery and treatment of wastewater. It is an open raceway pond that uses a paddlewheel for mixing water, while also having a higher pathogen treatment and nutrient removal efficiency over traditional wastewater treatment systems. To make the process even more economically feasible, the microalgal biomass that develops can be used as protein-rich feed, fertilizer, and most importantly for biofuel production (Sutherland et al., 2014). Biofuel production using HRAPs is popular as the extra costs of algal cultivation and biodiesel production associated with nutrient supply are taken care of by the nutrients present in wastewater or by the microalgal function of wastewater treatment (Mehrabadi et al., 2015). As it relies on algal photosynthesis, it operates best in arid, semi-arid, or tropical climates, and has been used for the treatment of wastewaters from domestic, tannery, dairy, and piggery sources. Removal of nitrogen is attributed to its assimilation into algal biomass and ammonia volatilization. Nitrogen removal in HRAPs is between 26.6 and $75.7 \%$ with $61.23 \%$ median, and ammonia removal is between 21.89 and $94 \%$ with a $77 \%$ median. Phosphorus in HRAPs on the other hand is removed by assimilation into biomass and by its $\mathrm{pH}$ dependent precipitation. Its removal range is around $10.48-97.2 \%$ with a 42.73\% median (Young et al., 2017). The High-Rate Algal Pond (HRAP) technology has been developed that has a $\mathrm{CO}_{2}$ addition function for improving algal growth (Figure 2).

In India, according to a report by the Central Pollution Control Board, New Delhi, only $20-30 \%$ of the 40 billion liters of wastewater generated is treated. This means like in many parts of the world the need for clean water and sustainable energy providing sources is of prime importance in India. Still algal growth on wastewater in HRAPs could only achieve $0.16 \mathrm{Mt}$ /annum of biofuel production, if the lipid fraction of algal cells is approximated to be $20 \%$. So even though HRAPs achieve high biomass contents, lipid productivities, and nutrient removal efficiencies, they do not compete well with other fuels whose use is still more economical and sustainable as per today's energy prices (Bhatt et al., 2014).

\section{Bacterial Treatment}

Bacteria are a critical requirement for the wastewater treatment strategy that was developed in the early 20th century and now serving as the principal of water treatment worldwide. Bacteria, some protozoans, and other microbes are confined to a tank in higher concentrations utilizing organic carbon as nutrient source. Therefore, the organic carbon in wastewater act as a stimulant of bacterial growth leading to natural purification prior to discharge. The microorganisms that treat the wastewater are collectively referred to as activated sludge (Davies, 2005).

The removal of nitrogen from wastewater involves three main processes, which are nitrification, denitrification, and anaerobic ammonia oxidation (anammox). In the nitrification process, aerobic chemo-lithoautotrophic ammonia-oxidizing bacteria $(\mathrm{AOB})$ and nitrite oxidizing bacteria (NOB) catalyze the two-step process in the given sequence respectively. The main ammonia oxidizer found in many systems is Nitrosococcus mobilis and the most important NOB in treatment plants are the bacteria of the genus Nitrosospira (Daims et al., 2006). Denitrification can either be a heterotrophic or an autotrophic process. In the heterotrophic route nitrate reduction following uptake is carried out using electron donors in the form of carbonaceous organic matter. Different species show differences in nitrogen metabolism when using different carbon sources, as in Anoxybacillus contaminans is shown to carry out both nitrification and aerobic denitrification in the presence of glucose, while Zoologea spp. showed $78.86 \%$ nitrate removal with sodium acetate as substrate (Rajta et al., 2020). Autotrophic denitrification is carried out by Sulfur oxidizing bacteria (SOB) that are capable Sulfur oxidizing autotrophic denitrification (SOAD) which uses reduced compounds like thiosulphate, sulfide, and elemental sulfur for reducing nitrate and nitrite. These reactions can be mediated by Proteobacteria of the genera Thiobacillus, Paracoccus, Sulfurimonas, and Thioalkalivibrio (Cui et al., 2019). In case of anammox, nitrite and ammonia combine to produce dinitrogen gas, and this requires aeration in the initial phase for the partial oxidation of ammonia to nitrite. Inhibition of NOB that uses nitrite as a substrate is also necessary. It removes nitrogen without addition of any extra organic carbon hence is suitable for high ammonia and low carbon content effluents. The bacteria that carry it out are members of the genus Planctomycetes which are chemolithoautotrophic, though they have slow growth rates and long build uptime in the initial working phase of anammox reactors (Daims et al., 2006). Nitrate reduction is carried out using assimilatory, dissimilatory, and denitrification pathways. Assimilatory pathways convert it to biomass, dissimilatory pathway to ammonium, and denitrification converts it to dinitrogen (Rajta et al., 2020).

The bacteria mediated biological removal of phosphorus from water using bacteria is achieved through the process of enhanced biological phosphorus removal (EBPR). This process exploits the ability of bacteria to accumulate polyphosphate inside their cells and selects for them using sequential aerobic and anaerobic phases. It uses two classes of bacteria, phosphorus accumulating 


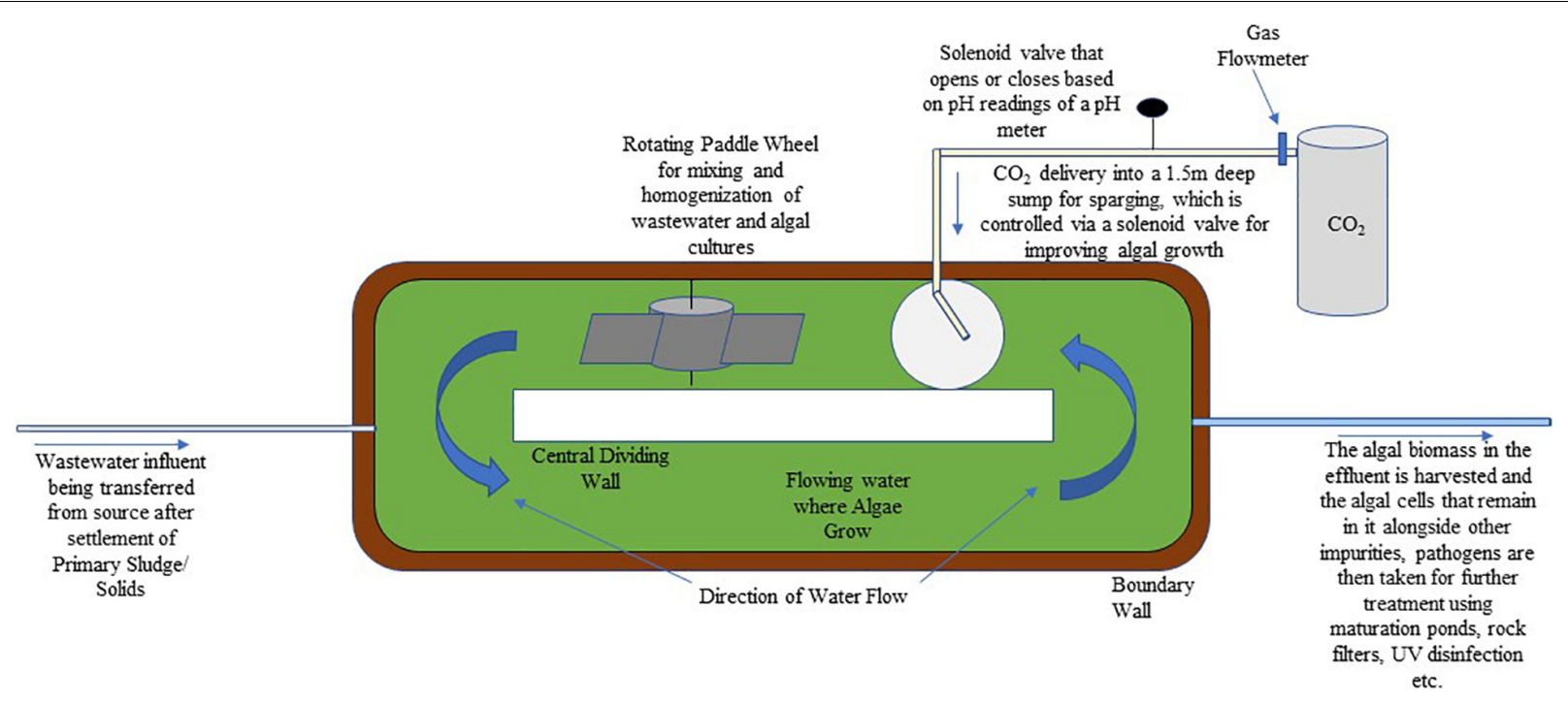

FIGURE 2 | A schematic showing a high-rate algal pond that has a $\mathrm{CO}_{2}$ addition function for improving algal growth.

organisms (PAO) and glycogen accumulating organisms (GAO). This process is at times unreliable as these two classes compete for carbon, hence leading to EBPR breakdowns. To avoid this, stimulating the growth of actinobacterial PAO over others is thought to help (Daims et al., 2006).

Organic matter present in wastewater is hydrolyzed by bacterial cells through the means of extracellular enzymatic hydrolysis as their cell walls prevent the process of phagocytosis. This is the case with particles in the size range $10^{3}$ amu$100 \mu \mathrm{m}$. Particles smaller than this can be directly taken up by cells and the ones larger are removed by sedimentation. Degradation processes are primarily de-polymerization reactions that are mostly performed through hydrolytic enzymes and in fewer cases through lyases. Exo-enzymes depolymerize at the ends that are usually the non-reducing ones, while endoenzymes depolymerize at the terminal monomers (Morgenroth et al., 2002). Once inside the cell, simpler compounds are used directly during feast period and the polymers formed during feast period are degraded to release simpler organic compounds in heterotrophic bacteria during times of starvation. This energy formed from catabolism is then used to fuel life processes like motility, ion gradient maintenance, transport of materials, and protein/nucleic acid turnover (Hao et al., 2010). Biological nutrient removal (BNR) is a function of bacterial metabolism and/or bacterial growth; hence, choosing species with higher rates of these two is ideal for this purpose (Pollard and Greenfield, 1997).

\section{The Factors Affecting the Treatment of Wastewater by Bacteria}

The factors affecting the treatment of wastewater by bacteria are:

(a) Anammox bacteria are found to be inactivated/eradicated at organic matter concentrations higher than $300 \mathrm{mg}$ $\mathrm{COD} / \mathrm{L}$ where the $\mathrm{COD}$ to nitrogen ratio is 2 , if anammox and denitrification processes happen sideside. This happens as they are unable to compete with denitrifying bacteria (Ni et al., 2012).

(b) Methanol concentration of $0.5 \mathrm{mM}$ is also found to completely and immediately inhibit anammox activity (Ni et al., 2012).

(c) The change of the organic compound composition changes from volatile fatty acids to sugars triggers the accumulation of Glycogen (Mulkerrins et al., 2004). These as stated before compete with Phosphate accumulating organisms hence causing EBPR breakdown (Daims et al., 2006).

(d) The co-transport of potassium and magnesium alongside phosphorus help in the stabilization of intracellular polyphosphate (Rickard and McClintock, 1992).

(e) Temperature affects microbial activity, gas transfer rates, and setting properties of biological solids. Every time temperature is increased by $10^{\circ} \mathrm{C}$, growth rates double. This means nutrient removal also increases, for example, at higher temperatures of $20-37^{\circ} \mathrm{C}$, biological phosphorus removal efficiency is said to increase (Mulkerrins et al., 2004).

(f) The accumulation of filamentous organisms prevents proper compaction and settling of sludges, hence reducing the quality of the effluent water (Wagner and Loy, 2002).

(g) Dissolved oxygen (DO) concentrations vary as per the treatment solution. The activated sludge systems need DO concentrations higher than $2 \mathrm{mg} / \mathrm{L}$ as they carry out processes like nitrification and carbon oxidation. On the other hand, the anaerobic zones of biological phosphorus removal systems must keep DO in the range $0.0-0.2 \mathrm{mg} / \mathrm{L}$ as substances like oxygen and nitrate interfere with biological phosphorus removal (Louzeiro et al., 2002).

(h) The process of nitrification is sensitive to $\mathrm{pH}$ and requires it to be 7.5-9, whereas denitrification happens at $\mathrm{pH}$ 7-8. Similarly, near neutral $\mathrm{pH}$ of around 7.2 is optimum for 
phosphorus removal, while acidic $\mathrm{pH}$ adversely affects this process (Mulkerrins et al., 2004).

(i) Heterotrophic Protists can help enhance nutrient cycling and carbon mineralization. This is done by them through either of the 3 hypothesized mechanisms, i.e., (a) their metabolisms cause release of $\mathrm{N}$ as ammonia or nitrate and $\mathrm{P}$ as phosphates which causes accelerated utilization of organic carbon by bacteria due to the need of maintaining their respective $\mathrm{C}: \mathrm{N}$ : P ratio, (b) they produce amino acids, vitamins, and nucleotides that helps enhance bacterial activity as they are growth promoting in nature, and (c) they graze on bacteria causing inefficient (more carbon must be dissimilated to obtain the same amount of biomass as compared to a more efficient species) species that grow fast to get selected such that additional organic carbon resource is utilized in the process (Pogue and Gilbride, 2007).

\section{Wastewater Treatment Using Up-Flow Anaerobic Sludge Blanket Reactor: A Bacterial Technology}

Anaerobic water treatment technologies have been used since the 19th century. Still, their treatment times are very slow if the water inflow volumes increased rapidly and had limited efficiency when compared to aerobic processes. This resulted in multiple modifications in their processes in the last part of the 20th century in terms of biomass accumulation, anaerobic metabolisms, effects of toxic compounds, and in the physiological interactions between different microbial species. These modifications made the anaerobic process an economically attractive alternative to the aerobic process (that is energy intensive) for the treatment of industrial wastewater in tropical to semi-tropical regions and even domestic wastewaters. One such treatment method is the up-flow anaerobic sludge blanket (UASB) process that Lettinga and coworkers developed in the 1970s (Bal and Dhagat, 2001). It is optimally used in high strength organic wastewater treatment as it produces high biomass concentrations and has a rich microbial diversity. This means that large volumes of organic wastes can be treated in compact reactors. The treatment performance is dependent on the granulation process, which is the formation of dense, multi-species microbial communities which cumulatively degrade complex organic wastes (Liu et al., 2003). The UASB reactor is of the vertical flow type that operates best in the mesophilic/thermophilic temperature range, with a solid, liquid, and gas phase separator that helps in the separation of biogas produced and helps return the dispersed sludge to sludge layer. Its operation and maintenance costs are $30 \%$ less than that required for the activated sludge process. The COD removal efficiencies for a UASB treating acidified food waste were recorded at $93 \%$ along with volatile fatty acid removal rates of 77-79\% (Nnaji, 2014). Some advantages of using this treatment strategy include effective handling of organic shock loads, reduced $\mathrm{CO}_{2}$ emissions, and biosolid waste generation in comparison to the aerobic process. Disadvantages are that pathogen removal is only partial and there is a need for post treatment due to incomplete nutrients removal by it (Latif et al., 2011). Figure 3 depicts the scheme of an Up-flow Anaerobic Sludge Blanket (UASB) reactor system.

\section{THE INTEGRATED BACTERIAL-MICROALGAL APPROACH FOR TREATMENT OF WASTEWATER}

Bacterial-microalgal approach is converging point of interest in industrial areas in the urge of improving the ecological status of the water resources, in particular for minimizing the phosphorus and nitrogen content in wastewater effluents. The ability of microalgae to utilize the organic and inorganic carbon, as well as inorganic nitrogen $(\mathrm{N})$ and phosphorus $(\mathrm{P})$ in wastewater for their growth, with the desired results of a reduction in the concentration of these substances in the water demands application of microalgae (Wollmann et al., 2019). Grady et al. (2011) estimated that the organic material of phytoplankton biomass fabricated from the discharge of $1 \mathrm{~kg}$ of $\mathrm{P}$ can exert $100 \mathrm{~kg}$ of $\mathrm{O}_{2}$ demand, while that produced from the discharge of $1 \mathrm{~kg}$ of $\mathrm{N}$ can exert $14 \mathrm{~kg}$ of $\mathrm{O}_{2}$ demand, due to this hypoxic or anoxic conditions species diversity is lost and overall functionality of aquatic ecosystem influenced. Threshold concentration of the range between $0.21-1.2 \mathrm{mg} \mathrm{L}^{-1}$ and $0.01-0.1 \mathrm{mg} \mathrm{L}^{-1}$ of total nitrogen (TN) and total phosphorus (TP), respectively, responsible for causing the eutrophication, was evaluated by Chambers et al. (2012).

Mostly, $\mathrm{P}$ is considered as the rate limiting nutrient for phytoplankton growth; hence, for mitigating the eutrophication, there is a need to reduce the input of Phosphorous into the receiving systems (Hendriks and Langeveld, 2017). For example, in Denmark, a TP effluent concentration of $0.3 \mathrm{mg} \mathrm{L}^{-1}$ is applied to all municipal treatment facilities, whereas in Sweden a $90 \%$ reduction is required (compared to $80 \%$ reduction in relation to the load of the influent stated by the UWTD). The complex removal process of the $\mathrm{N}$ and $\mathrm{P}$ requires a separate environment which requires high energy which substantially results in the increases of overall cost of the treatment (Grady et al., 2011). The sustainable alternative to energy intensive and conventional biological treatment processes which is environmentally friendly as well includes the eukaryotic algae and cyanobacteria (Singh et al., 2015). Almomani et al. (2019) stated that the use of microalgae in wastewater treatment is a cost effective and feasible method for bio-fixation of $\mathrm{CO}_{2}$, in addition to being a renewable source for biomass. Along with the ability of microalgae to utilize the $\mathrm{N}$ and $\mathrm{P}$, another advantage of using the microalgae into wastewater treatment is the generation of the oxygen by the process of photosynthesis. The microalgae have the ability to utilize the organic nitrogen and the inorganic nitrogen if available in the form of ammonium/ammonia as nitrite and nitrates.

Further, the added benefit of using integrated approach has been elucidated by Sturm and Lamer (2011) and Gouveia et al. (2016). According to authors, in the case of the wastewater treatment by an algal-bacterial co-culture approach, we need not to switch between the different operating environments to facilitate inorganic $\mathrm{N}$ and $\mathrm{P}$ removal, it just requires the single stage treatment, which in result reduces the complexity of the 


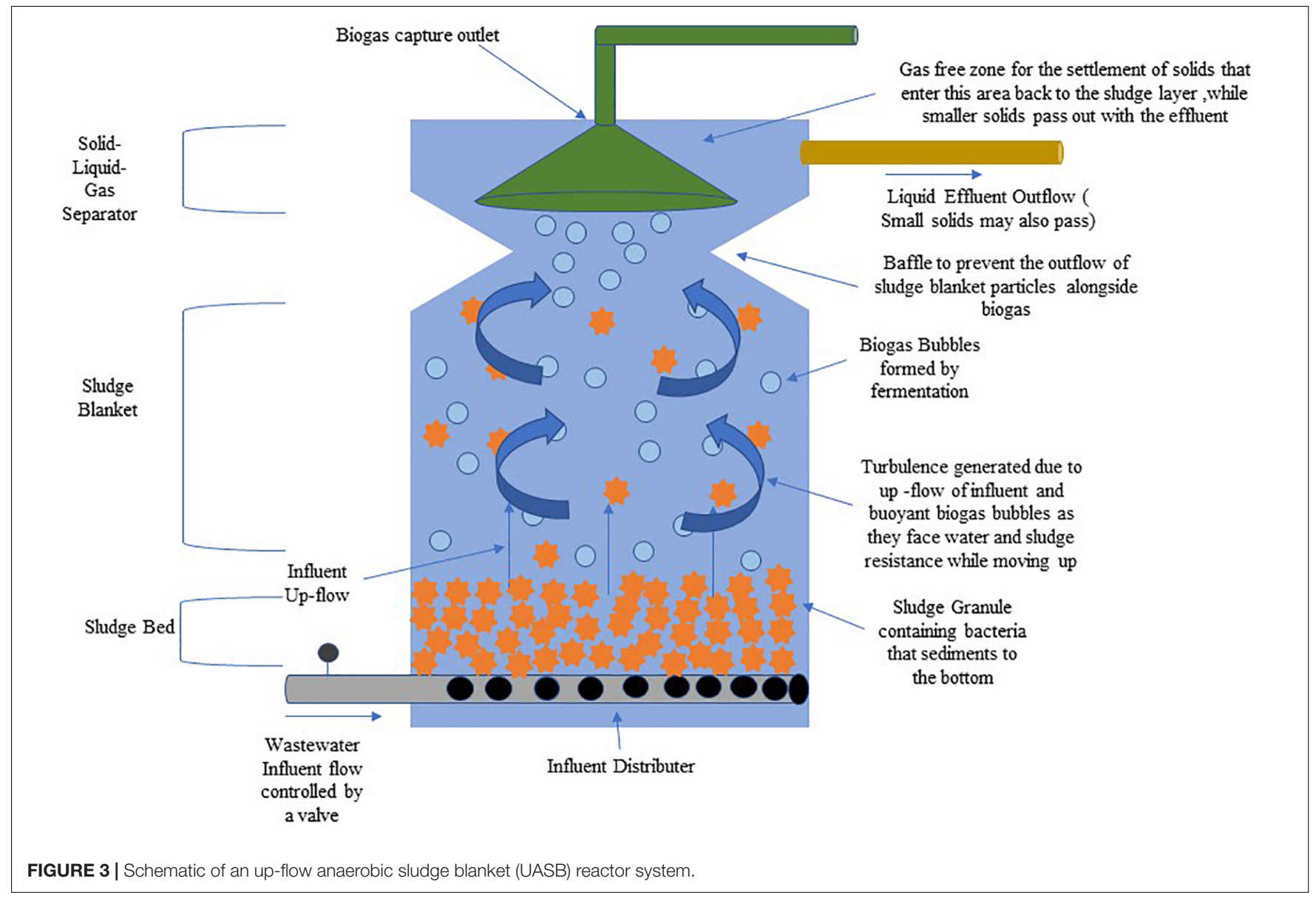

treatment process (Figure 4). Microalgae assimilate ammonia $\left(\mathrm{NH}_{3}\right)$ and phosphate $\left(\mathrm{PO}_{4}\right)$ directly and in concert for cell growth and metabolic function (Falkowski and Raven, 2007; Borowitzka et al., 2016). As the majority of $\mathrm{N}$ is being assimilated instead of being converted into oxides of nitrogen, the microalgae mediated treatment process releases lesser greenhouse gas than the conventional treatment. There is a negligible emission of Nitrogen Oxides using microalgal association in the wastewater treatment process (Fagerstone et al., 2011; Guieysse et al., 2013). Based on the analysis of Alcántara et al. (2015), a microalgae wastewater treatment process is estimated to have an emission factor of $0.0047 \% \mathrm{~g} \mathrm{~N}_{2} \mathrm{O}-\mathrm{N} \mathrm{g}^{-1} \mathrm{~N}$-input. A number of studies which were done using microalgal species on different wastewater types include municipal, agricultural, brewery, refinery, and industrial effluents with different efficiencies, and this investigation into the biological removal of carbonaceous, nitrogenous, and phosphorus has been evaluated (Cai et al., 2013; Gentili, 2014; Chiu et al., 2015).

Ji et al. (2013) and Prandini et al. (2016) have demonstrated that the strain Scenedesmus obliquus successfully removed nutrients (carbon, $\mathrm{N}$ and $\mathrm{P}$ ) from piggery wastewater. Kothari et al. (2012) showed that Chlorella pyrenoidosa after wastewater acclimatization (at a $75 \%$ concentration optimum) is seen to successfully grow in the dairy wastewater effluent while also reducing mineral concentrations and chemical characters like
TS (total solids) and Hardness. Some species of Chlorella such as C. vulgaris have also been reported using $\mathrm{N}$ and $\mathrm{P}$ from the municipal wastewater effluent at the primary stage of the treatment $\left(\mathrm{PO}_{4}{ }^{3-}-\mathrm{P}: 8-3 \mathrm{mg} \mathrm{L}^{-1} ; \mathrm{NH}_{4}{ }^{+}: 119-\right.$ $\left.37 \mathrm{mg} \mathrm{L}{ }^{-1}\right)$, secondary stage $\left(\mathrm{PO}_{4}{ }^{3-}-\mathrm{P}: 6.1-0.5 \mathrm{mg} \mathrm{L}^{-1}\right.$; $\mathrm{NH}_{4}{ }^{+}-\mathrm{N}$ : $6.9-0.8 \mathrm{mg} \mathrm{L}^{-1}$ ), and from centrate (TP: 215$40 \mathrm{mg} \mathrm{L}^{-1}$; TN: $116-12 \mathrm{mg} \mathrm{L}^{-1}$, Gouveia et al., 2016). Choi (2016) have proved that the reported $88 \%$ biological oxygen demand (BOD), $82 \% \mathrm{TN}$, and 54\% TP have been successfully removed from the initial concentrations in the brewery effluent using C. vulgaris. Other micro-algae species examined for their bioremediation potential include Chlamydomonas sp., Nannochloropsissp., Dunaliella sp., Spirulina sp., and Botryococcu sp. (Cuellar-Bermudez et al., 2015; Gonçalves et al., 2017). The amount of nutrients utilized by the microalgae is closely associated with their growth (Xin et al., 2010; Al Ketife et al., 2017) limiting the supply of these nutrients can also limit or reduce their growth. So, optimal ratio of nutrients that is essential for the microalgal must be present in the cultivation media to ensure the optimal removal of $\mathrm{N}$ and $\mathrm{P}$. The traces of the micronutrient which are essential such as the calcium, magnesium, potassium, manganese, silica, zinc, iron, and other are generally present in the abundant amount in the wastewater (Falkowski and Raven, 2007; Borowitzka and Moheimani, 2013). 


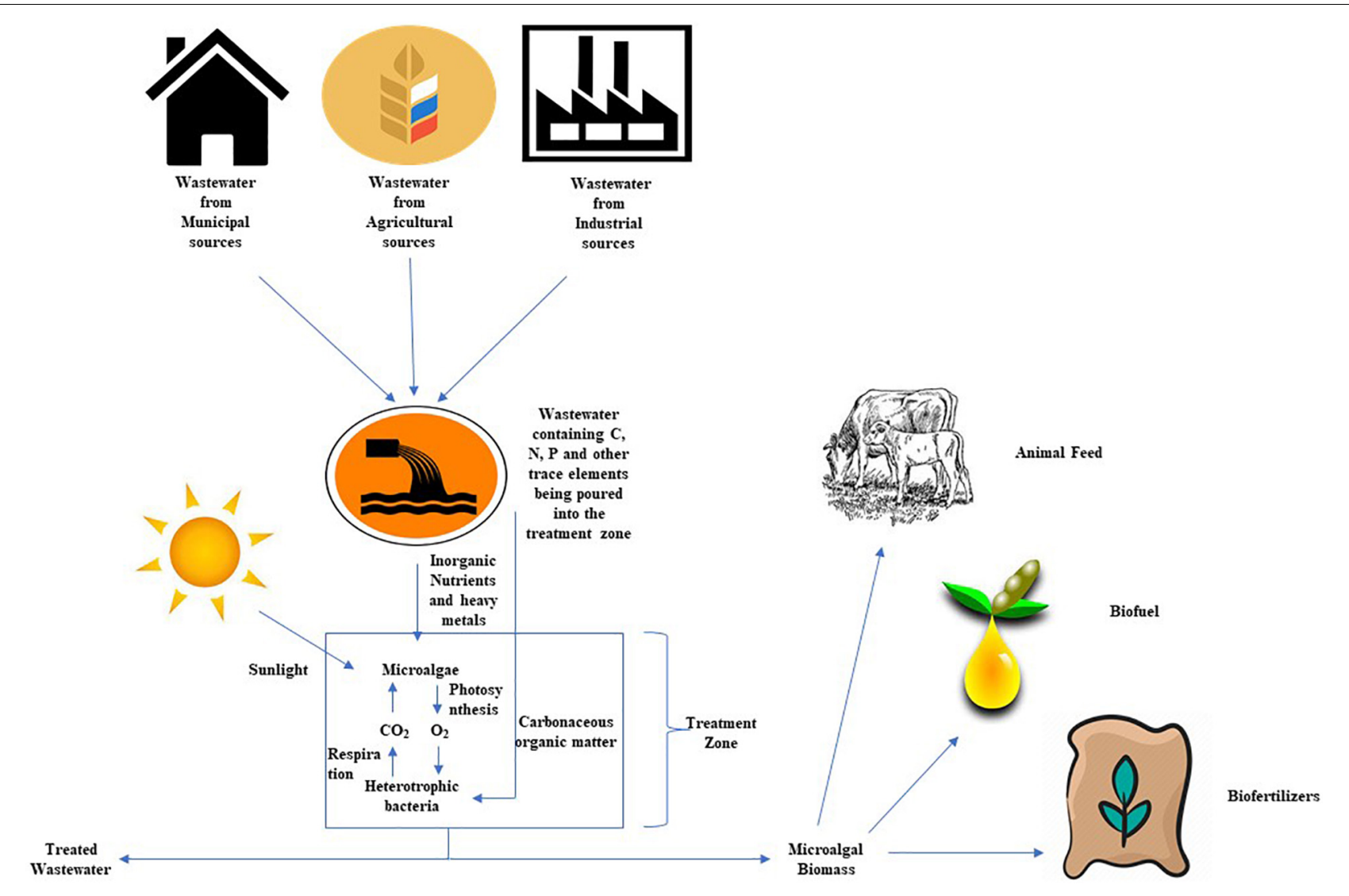

FIGURE 4 | Integrating algae and bacteria for the degradation of wastewater contaminants.

The microalgal removal efficiencies differ with the different concentration of the $\mathrm{C}, \mathrm{N}$, and P. Chlorella sp. had an improved efficiency in inorganic $\mathrm{N}$ and $\mathrm{P}$ removal associated with the higher average specific growth rate in PSW (poultry slaughterhouse water) as compared to STE (secondary treatment effluent, Wang et al., 2010). In total, $68.5 \%$ of $\mathrm{TN}$ and $90.6 \%$ of TP is the removal capacity of this species microalgae from the PSW, and from the STE the removal capacity is $50.8 \% \mathrm{TN}$ and $4.96 \%$ TP. Furthermore, a decline of $56.5 \%$ was observed in the level of COD from the PSW, and an increase of $22.7 \%$ was recorded in the STE which signifies that the microalgae produces the oxidizable carbon matter. Various studies showed that in respect to the bioavailable ( $\mathrm{N}$ and $\mathrm{P}$ ) the ability of microalgae to grow and treat wastewater deviates from the canonical $\mathrm{N}$ and $\mathrm{P}$ stoichiometry of freshwater microalgae. For example, a lower residual concentration when the synthetic water is treated with the microalgae C. vulgaris after establishing an optimum $N: P$ ratio (Klausmeier et al., 2004; Xin et al., 2010; Borowitzka et al., 2016). A decrease from 5.1 to $2 \mathrm{mg} \mathrm{L}^{-1}$ was noticed in this study when the $N: P$ ratio was increased from $4: 1$ to $8: 1$ and a significant decline in removal efficiency occurred as a result of the increasing ratio. Al Ketife et al. (2017) showed a slightly higher optimal ratio of $\mathrm{N}$ and $\mathrm{P}$ for a different $C$. vulgaris strain, with the complete removal of $\mathrm{N}$ and $\mathrm{P}$ which is achieved at a ratio of 10:1. Similarly, Arbib et al. (2017) examined that the ratio of $\mathrm{N}$ and $\mathrm{P}$ should be between 9:1 and 13:1 for the efficient removal of the nutrients for $S$. obliquus species. Number of studies on various culturing techniques have proved the success of incorporating microalgae in treating the PSW. According to Choi (2015) upto $96.38 \%$ of TN and $92.7 \%$ of TP was removed from Municipal Wastewater upon treating it in a microalgal bioreactor containing a C. vulgaris culture. Further, Ramos Tercero et al. (2014) and Almomani and Örmeci (2016) reported the efficiencies of $63.2 \% \mathrm{NH}_{4}{ }^{+}-\mathrm{N}, 32.4 \%$ total dissolved $\mathrm{P}$, and $64.9 \%$ removal from the PSW using a native microalgal species. These removed nutrients are used for algal biomass generation, and Table 2 shows the rate at which this happens in different algal species.

Algal based wastewater treatment is more sustainable compared to bacterial based wastewater treatment (Kohlheb et al., 2020). This has been proved by HRAP which is more beneficial than activated sludge based sequencing batch reactors (SBR) both environmentally as well as economically. This is because the total electricity consumption of HRAP is only $22 \%$ of the electricity consumption of SBR. Also at discount rates of 0.25 and $3 \%$ the life cycle costs of HRAP to SBR was found to be $0.182 € / \mathrm{m}^{3}$ vs. $0.258 € / \mathrm{m}^{3}$ and $0.125 € / \mathrm{m}^{3}$ vs. $0.167 € / \mathrm{m}^{3}$, respectively. Also, the global warming potential in terms of net $\mathrm{CO}_{2}$ production for HRAP to SBR was 146.27 vs. $458.27 \times 10^{-3} \mathrm{~kg} \mathrm{CO}_{2}$ equiv. $/ \mathrm{m}^{3}$, respectively. Similarly, 
TABLE 2 | Showing the rate at which different microalgal species grow by assimilating nutrients into their biomass under specific condition sets.

\begin{tabular}{|c|c|c|c|}
\hline Microalgae & $\begin{array}{l}\text { Taxonomic } \\
\text { order }\end{array}$ & $\begin{array}{c}\text { Biomass } \\
\text { productivity } \\
\text { as per studies } \\
\text { (kg/m³/day) }\end{array}$ & References \\
\hline $\begin{array}{l}\text { Chlorella } \\
\text { vulgaris }\end{array}$ & Chlorellales & 0.35 & Blair et al., 2014 \\
\hline $\begin{array}{l}\text { Chlorella } \\
\text { sorokiniana }\end{array}$ & Chlorellales & 0.85 & Ugwu et al., 2007 \\
\hline $\begin{array}{l}\text { Chlamydomonas } \\
\text { sp. (YG04) }\end{array}$ & Chlamydomonadales & 0.0552 & Shekh et al., 2016 \\
\hline $\begin{array}{l}\text { Coelastrum } \\
\text { microporum }\end{array}$ & Sphaeropleales & 0.044 & Hussain et al., 2020 \\
\hline Oocystis sp. & Chlorellales & 0.02524 & $\begin{array}{l}\text { Mohammadi et al., } \\
2018\end{array}$ \\
\hline $\begin{array}{l}\text { Chlorella } \\
\text { zofingiensis }\end{array}$ & Chlorellales & $\begin{array}{c}0.29616 \pm \\
0.01916\end{array}$ & Li et al., 2019 \\
\hline $\begin{array}{l}\text { Scenedesmus } \\
\text { obliquus }\end{array}$ & Sphaeropleales & 0.29250 & Ho et al., 2010 \\
\hline $\begin{array}{l}\text { Scenedesmus } \\
\text { dimorphus }\end{array}$ & Sphaeropleales & 0.09 & Chng et al., 2017 \\
\hline $\begin{array}{l}\text { Mucidosphaerium } \\
\text { pulchellum }\end{array}$ & Chlorellales & $0.1889 \pm 0.010$ & $\begin{array}{l}\text { Mehrabadi et al., } \\
2017\end{array}$ \\
\hline
\end{tabular}

eutrophication potential in terms of phosphate release was 126.14 vs. $158.01 \times 10^{-6} \mathrm{~kg} \mathrm{PO}_{4}$ equiv. $/ \mathrm{m}^{3}$, respectively.

\section{Merits and Demerits of the Integrated Bacterial-Microalgal Approach for Treatment of Wastewater}

On one hand, the integrated approach has some merits to its usability (Katam and Bhattacharyya, 2021). These include the (a) ability for single step removal of nutrients and organic carbon, (b) such systems have lower requirement for mechanical aeration, due to which their carbon footprint is less, (c) resourceful biomass generated in the form of biomass that can be used for the synthesis of biodiesel or biogas, (d) lower quantities of sludge generated in comparison to typical treatment technologies that use bacteria, and (e) the wastewater effluent produced is disinfected from pathogens within the system due to which additional chemicals are not required later. On the other hand, they have found certain demerits of this approach too, which are (a) light dependency of microalgal growth which is not true for pure activated sludge process, (b) high $\mathrm{pH}$ of medium generated due to photosynthesis by microalgae that negatively impacts the bacterial consortium associated with the activated sludge process, (c) the slow growth rate of microalgae which leads to higher Solid Retention Time (SRT) than what is required by heterotrophic organisms, and (d) difficulty associated with the separation of microalgal biomass from the mixed liquor so that lipids and pigment can be extracted. Other than these, treatment of the wastewater using microalgae faces more challenges which includes dealing with the large volumes of wastewater that needs to be treated. Hoh et al. (2016) stated that the various microalgae cultivation processes need to be reviewed to come out with (a) optimal microalgal productivity, (b) for ensuring the higher effectiveness of the nutrient removal, and (c) to deal with large volumes. The wastewater treatment process is also largely affected by the design and configuration of the reactor controlling measures like light and temperature which have influence on the growth of microalgae (Mata et al., 2010). Christenson and Sims (2011) have classified the different microalgal techniques broadly into two categories either suspended or immobilized systems. The two systems are further classified as either open or closed systems. Hoh et al. (2016) stated that the different types of bioreactors are considerably important when looking at the efficiency of the wastewater treatment and the biomass productivity. As per the Swedish EPA (2008), in anticipation of the getting the lower set standards, the performance of the treatment process should be able to meet the current required effluent concentrations which has been set by the UWTD (urban wastewater treatment directive).

Smaller the reactor system shorter will be its HRT (hydraulic retention time), which makes it better for saving capital costs and helps in optimizing the surface area requirement (Metcalf and Eddy, 2003; Ruiz et al., 2013). Several studies suggested that out of immobilized and suspended cultivation systems, a shorter treatment duration is observed in PBR (photobioreactor) suspended systems, with higher $\mathrm{N}$ and $\mathrm{P}$ removal efficiency despite the various operating parameters like biomass inoculation concentration, temperature, and irradiance. In PBR suspended systems, an average $87.3 \% \mathrm{~N}$ and $82.9 \% \mathrm{P}$ removal efficiency was achieved, within an average of 3.1 days (or HRT, Choi, 2015). Some current evidence shows that the integration of microalgae with bacteria for wastewater treatment is a technologically and environmentally feasible option. When microalgae is used as the option for the removal of nitrogenous, phosphorous, carbonaceous material, it works at a lower footprint in terms of the energy consumption and greenhouse gas generation as compared with the conventional wastewater treatment process.

In current times, decentralization of wastewater treatment has become necessary as centralized wastewater treatment plants (WWTPs) have not been able to keep up with the pressure of catering to the ever increasing population in urban areas. They are also unable to expand their current capacities as most of them are located in cities where there is a space constraint. The application of the integrated approach in addressing this problem has been studied by Katam and Bhattacharyya (2021). According to authors, the application of algal biofilms to an already existing ASP (activated sludge process) based DWWTP (decentralized wastewater treatment plant) in Hyderabad, India leads to a significant enhancement of carbon and nutrient removal from the influent wastewater inside a single reactor. For this purpose, the algae have been provided with the optimal light intensity, photoperiod, and immobilized using a suitable technique (Katam and Bhattacharyya, 2021).

\section{Factors Influencing Bacteria-Microalgae Wastewater Treatment}

Bacteria, industrial contaminants, $\mathrm{pH}$, light, and temperature are some biotic and abiotic factors that influence the course of action of the microalgal wastewater treatment. Bacteria is an important 
factor whose presence has a positive influence on the microalgaebacteria wastewater treatment process. Bacteria is mandatory and essential for microalgae as through its heterotrophic metabolism it may support the growth of the microalgae by providing $\mathrm{CO}_{2}$ mineralizing it into a form of inorganic compounds which can be directly taken up by the microalgae. In return, the microalgae provide $\mathrm{O}_{2}$ generated during the process of photosynthesis required by the heterotrophic bacteria for degrading the organic matter and again required back by the microalgae during dark respiration (Falkowski and Raven, 2007). $\mathrm{Su}$ et al. (2011) reported that during the treatment process of primary sewage waste with the microalgal consortium resulted in the enrichment of certain bacterial species which are dominated by the members of the classes Bacteroidia (50\%), Flavobacteria (25\%), Betaproteobacteria (12.5\%), and Gammaproteobacteria. In a subsequent study, for investigating the removal efficiency of contaminants from PSW, Su et al. (2011) inoculated the sludge with the different microalgal ratios and found fluctuations in the occurrence of bacterial community composition among the treatments of different inoculation ratios. In contrast, other studies (Schumacher et al., 2003; Ansa et al., 2011; Sousa, 2013) have mentioned that the bacteria and microalgae have adverse effects on each other via some abiotic factor. Bacterial activity was highly affected by an increase in the $\mathrm{pH}$ and dissolved $\mathrm{O}_{2}$ in the algal cultures. Another study shows a strong interrelation between the abundance of bacteria (heterotrophic bacteria) and $\mathrm{pH}$ which shows the negative impact of inactivation of bacteria with increasing pH (Awuah et al., 2001; Ansa et al., 2011, Ansa et al., 2012). Temperature also has a great influence on the microalgae-bacteria wastewater treatment as it is highly necessary for normal functioning of the microalgae as the energy captured by them from the light help in driving the $\mathrm{O}_{2}$ evaluation process to generate the ATP and the reducing agents that are required for fixing $\mathrm{CO}_{2}$ into organic carbon (Falkowski and Raven, 2007; Williams and Laurens, 2010).

Proper maintenance of microalgal growth promoting environment is necessary as the nutrient deficient condition might induce resource competition between the existing microbial community and exogenous microalgae (Grover, 2000). Certain studies have described a saturation point below that the rate of photosynthetic activity is proportional to the irradiance intensities, receptor system become damaged resulting into photo-inhibitions if the intensities above the saturation point is illuminated (Falkowski and Raven, 2007; Williams and Laurens, 2010). This illumination intensity may vary with respect to the microalgal species and temperature. Generally, the illumination saturation point are found to fall between 200 and $400 \mu \mathrm{E} \mathrm{m}^{-2}$ $\mathrm{s}^{-1}$ for the freshwater microalgae (Muñoz and Guieysse, 2006; Cheirsilp and Torpee, 2012; Singh and Singh, 2015). Therefore, maintaining the culture system at or below the saturation point is another important and practical part in order to avoid excessive light utilization by algae and also to avoid over expenditure of energy. The illumination period and the intensities have a link to removal efficiency of the inorganic $\mathrm{N}$ and $\mathrm{P}$ from the wastewater. Lee et al. (2015) reported a reduction in the capacity, when the removal of $\mathrm{N}$ and $\mathrm{P}$ from the wastewater is allowed with the microalgal-bacterial consortium under prolonged dark conditions.

\section{CONCLUSION AND FUTURE PERSPECTIVES}

In India and other developing countries, $50-80 \%$ of the wastewater is discharged untreated or partially treated. The amount of wastewater is increasing day by day in tune with urbanization and global population increase. The conventional sewage treatment systems like activated sludge fail to reduce nutrient concentration of wastewaters to acceptable levels for preventing rapid rate of eutrophication in the vicinity of sewage discharge sites. The addition of microalgae to the sewage treatment has multiple applications such as (a) removal of excess inorganic nitrogen, phosphorus, and heavy metals, (b) nonproliferation of pathogenic bacteria, (c) microalgae mediated $\mathrm{CO}_{2}$ sequestration, and (d) use of microalgae for biofuel production. The integrated bacterial-microalgal approach proves to be even more promising as the heterotrophic bacteria have potential to degrade the organic matter in the absence of aerated $\mathrm{O}_{2}$, as $\mathrm{O}_{2}$ is provided by the microalgal photosynthesis and similarly the need for $\mathrm{CO}_{2}$ sparging is also eliminated as this is produced by the bacterial respiration. Therefore, the integrated approach of bacteria-microalgae wastewater treatment would require single stage treatment reducing the complexity of the treatment process. Heterotrophic bacteria utilize the organic compounds of the waste water and produce $\mathrm{CO}_{2}$, whereas the microalgae in turn utilize this $\mathrm{CO}_{2}$ to produce carbohydrates and $\mathrm{O}_{2}$ through photosynthesis, of which the former is needed for biomass production, while the latter serves as the terminal electron acceptor for aerobic respiration in bacteria. So the application of heterotrophic bacteria and autotrophic protists (algae) has the potential to complement each other, making them easy to handle and safe to be used by people. This cyclical, almost self-reliant water treatment method with the added benefit of microalgal biomass could provide the right balance between expenditure and the access to clean water to the citizens, where wastewater treatment is rare, environment protection standards are not stringent, and water borne diseases are common. Being eco-friendly, safe to handle and cost effective such a system can be applied in a decentralized manner at source rather than the conventional STPs that need a centralized large scale plant. In tune with increasing amount of waste water load and aiming to have good biomass yields optimizing the relative proportion of microalgae and bacterial consortium further research is needed to be done in this area. This requires critical understanding of interactions between the necessary bacterial species and microalgae to stabilize treatment processes and their growth promoting factors, like $\mathrm{pH}$ level, temperature, and nutrient concentration. Ways to monitor and provide a continuous supply of nutrients and light must be ensured (mainly in closed systems) for optimal performance. In wastewater discharge zone meiobenthos are observed in high numbers, and they are known to utilize organic debris settled at the bottom. The possibility 
of adding meiobenthic fauna (benthic metazoans that can pass through a $500 \mu \mathrm{m}$ filter, but which are retained on a $40 \mu \mathrm{m}$ one) could also be evaluated alongside bacteria and microalgae. This is attributed to their ability to feed on particulate organic matter, thus hastening the process of degradation of organics. They could also act as the predators of the bacteria that make biofilms in the filters used for physical treatment of wastewater, hence providing a natural alternative for cleaning them. The bacterial biomass developed during the treatment process could also be diverted toward these meiobenthos, hence reducing their numbers in the effluent naturally rather than relying on physical and chemical disinfection processes like UV or chlorine treatment. Still, the inclusion of such disinfection processes may provide superior performance.

\section{REFERENCES}

Abou-Shanab, R. A. I., Ji, M. K., Kim, H. C., Paeng, K. J., and Jeon, B. H. (2013). Microalgal species growing on piggery wastewater as a valuable candidate for nutrient removal and biodiesel production. J. Environ. Manage. 115, 257-264. doi: 10.1016/j.jenvman.2012.11.022

Ahmed, S. F., Mofijur, M., Parisa, T. A., Islam, N., Kusumo, F., Inayat, A., et al. (2022). Progress and challenges of contaminate removal from wastewater using microalgae biomass. Chemosphere 286(Pt 1):131656. doi: 10.1016/j. chemosphere.2021.131656

Al Ketife, A. M., Judd, S., and Znad, H. (2017). Synergistic effects and optimization of nitrogen and phosphorus concentrations on the growth and nutrient uptake of a freshwater Chlorella vulgaris. Environ. Technol. 38, 94-102. doi: 10.1080/ 09593330.2016.1186227

Alcántara, C., Domínguez, J. M., García, D., Blanco, S., Pérez, R., García-Encina, P. A., et al. (2015). Evaluation of wastewater treatment in a novel anoxicaerobic algal-bacterial photobioreactor with biomass recycling through carbon and nitrogen mass balances. Bioresour. Technol. 191, 173-186. doi: 10.1016/j. biortech.2015.04.125

Alexandre, C. L., Antonio, V., Diego, L., and Cristina, G. F. (2018). Energy balance and life cycle assessment of a microalgae-based wastewater treatment plant: a focus on alternative biogas uses. Bioresour. Technol. 270, 138-146. doi: 10.1016/ S0960-8524(00)00136

Almomani, F. A., and Örmeci, B. (2016). Performance of Chlorella vulgaris, Neochloris oleoabundans, and mixed indigenous microalgae for treatment of primary effluent, secondary effluent and centrate. Ecol. Eng. 95, 280-289. doi: 10.1016/j.ecoleng.2016.06.038

Almomani, F., Ketife, A. A., Judd, S., Shurair, M., Bhosale, R. R., Znad, H., et al. (2019). Impact of $\mathrm{CO}^{2}$ concentration and ambient conditions on microalgal growth and nutrient removal from wastewater by a photobioreactor. Sci. Total Environ. 662, 662-671. doi: 10.1016/j.scitotenv.2019.01.144

Amini, S. R., Najafabady, N. M., Shaker, S., Safari, A., Kazemi, A., Mousavi, P., et al. (2014). Removal of nitrogen and phosphorus from wastewater using microalgae free cells in bath culture system. Biocatal. Agric. Biotechnol. 3, 126-131. doi: 10.1016/j.bcab.2013.09.003

Ansa, E. D. O., Lubberding, H. J., Ampofo, J. A., and Gijzen, H. J. (2011). The role of algae in the removal of Escherichia coli in a tropical eutrophic lake. Ecol. Eng. 37, 317-324. doi: 10.1016/j.ecoleng.2010.11.023

Ansa, E. D. O., Lubberding, H. J., and Gijzen, H. J. (2012). The effect of algal biomass on the removal of faecal coliform from domestic wastewater. Appl. Water Sci. 2, 87-94. doi: 10.1007/s13201-011-0025-y

Arbib, Z., de Godos, I., Ruiz, J., and Perales, J. A. (2017). Optimization of pilot high rate algal ponds for simultaneous nutrient removal and lipids production. Sci. Total Environ. 589, 66-72. doi: 10.1016/j.scitotenv.2017.02. 206

Arora, K., Kaur, P., Kumar, P., Singh, A., Patel, S. K. S., Li, X., et al. (2021). Valorization of wastewater resources into biofuel and value-added products using microalgal system. Front. Energy Res. 9:646571. doi: 10.3389/fenrg.2021. 646571

\section{AUTHOR CONTRIBUTIONS}

MM, KK, VV, and RD wrote the original draft of the manuscript. $\mathrm{RD}$ supervised the manuscript. $\mathrm{RD}$ and $\mathrm{MM}$ conceived the concept and designed of the manuscript. RK gave critical feedback and edited the manuscript. H-UD and J-SH contributed to the revision of the manuscript. All authors contributed to the article and approved the submitted version.

\section{ACKNOWLEDGMENTS}

The authors are thankful to both the reviewers for their constructive comments.

Arun, M. (2011). Biological wastewater treatment. Water 33, 35-42.

Awuah, E., Anohene, F., Asante, K., Lubberding, H., and Gijzen, H. (2001). Environmental conditions and pathogen removal in macrophyte- and algalbased domestic wastewater treatment systems. Water Sci. Technol. 44, 11-18. doi: 10.2166 /wst.2001.0329

Bal, A. S., and Dhagat, N. N. (2001). Upflow anaerobic sludge blanket reactor - a review. Indian J. Environ. Health 43, 1-82.

Benedetti, M., Vecchi, V., Barera, S., and Osto, L. (2018). Biomass from microalgae: the potential of domestication towards sustainable biofactories. Microb. Cell Fact. 17:173. doi: 10.1186/s12934-018-1019-3

Bhatt, N. C., Panwar, A., Bisth, T. S., and Tamata, S. (2014). Coupling of algal biofuel production with wastewater. Sci. World. 10:210504. doi: 10.1155/2014/ 210504

Bjorn, G., Marino, B., and Martin, T. P. (2006). Effects of wastewater treatment plant discharge on ecosystem structure and function of lowland streams. J. N. Am. Benthol. Soc. 25:38063. doi: 10.1371/journal.pone.0038063

Blair, M. H., Kokabian, B., and Gude, V. G. (2014). Light and growth medium effect on Chlorella vulgaris biomass production. J. Environ. Chem. Eng. 2, 665-674. doi: 10.1016/j.jece.2013.11.005

Borowitzka, M. A., Beardall, J., and Raven, J. (2016). The Physiology of Microalgae. Dordrecht: Springer, doi: 10.1007/978-3-319-24945-2

Borowitzka, M. A., and Moheimani, N. R. (2013). Algae for Biofuels and Energy. Dordrecht: Springer, doi: 10.1007/s11027-011-9294-X

Cai, T., Park, S. Y., and Li, Y. (2013). Nutrient recovery from wastewater streams by microalgae: status and prospects. Renew. Sust. Energ. Rev. 19, 360-369. doi: 10.1016/j.rser.2012.11.030

Chambers, P. A., McGoldrick, D. J., Brua, R. B., Vis, C., Culp, J. M., and Benoy, G. A. (2012). Development of environmental thresholds for nitrogen and phosphorus in streams. J. Environ. Qual. 41:273. doi: 10.2134/jeq2010.0273

Cheirsilp, B., and Torpee, S. (2012). Enhanced growth and lipid production of microalgae under mixotrophic culture condition: effect of light intensity, glucose concentration and fed-batch cultivation. Bioresour. Technol. 110, 510516. doi: 10.1016/j.biortech.2012.01.125

Chia, Y. C., Tzu-Yao, W., and Gen-Schuh, W. (2007). Determining estrogenic steroids in Taipei waters and removal in drinking water treatment using high-flow solid-phase extraction and liquid chromatography/tandem mass spectrometry. Sci. Total Environ. 378, 352-365. doi: 10.1016/j.scitotenv.2007. 02.038

Chiu, S. Y., Kao, C. Y., Chen, T. Y., Chang, Y. B., Kuo, C. M., and Lin, C. S. (2015). Cultivation of microalgal Chlorella for biomass and lipid production using wastewater as nutrient resource. Bioresour. Technol. 184, 179-189. doi: 10.1016/j.biortech.2014.11.080

Chng, L. M., Lee, K. T., and Chan, D. J. C. (2017). Synergistic effect of pretreatment and fermentation process on carbohydrate-rich Scenedesmus dimorphous for bioethanol production. Energy Convers. Manag. 141, 410-419. doi: 10.1016/j.enconman.2016.10.026

Choi, H. (2015). Intensified production of microalgae and removal of nutrient using a microalgae membrane bioreactor (MMBR). Appl. Biochem. Biotechnol. 175, 2195-2205. doi: 10.1007/s12010-014-1365-5 
Choi, H.-J. (2016). Parametric study of brewery wastewater effluent treatment using Chlorella vulgaris microalgae. Environ. Eng. Res. 21, 401-408. doi: 10.4491/eer. 2016.024

Christenson, L., and Sims, R. (2011). Production and harvesting of microalgae for wastewater treatment, biofuels, and bioproducts. Biotechnol. Adv. 29, 686-702. doi: 10.1016/j.biotechadv.2011.05.015

Cristine, S., Benjamin, F., Kirsten, L., Luis, E. M., Georg, S., and Martin, H. (2011). Sodium overload and water influx activate the NALP3 inflammasome. Biological. Chem. 286, 35-41.

Cuellar-Bermudez, S. P., Garcia-Perez, J. S., Rittmann, B. E., and Parra-Saldivar, R. (2015). Photosynthetic bioenergy utilizing $\mathrm{CO}_{2}$ : an approach on flue gases utilization for third generation biofuels. Clean. Prod. 98, 53-65. doi: 10.1016/j. jclepro.2014.03.034

Cui, Y. X., Biswal, B. K., Guo, G., Deng, Y. F., Huang, H., Chen, G. H., et al. (2019). Biological nitrogen removal from wastewater using sulphur-driven autotrophic denitrification. Appl. Microbiol. Biotechnol. 103, 6023-6039. doi: 10.1007/s00253-019-09935-4

Daims, H., Taylor, M. W., and Wagner, M. (2006). Wastewater treatment: a model system for microbial ecology. Trends Biotechnol. 24, 483-489. doi: 10.1016/j. tibtech.2006.09.002

Davies, P. S. (2005). The Biological Basis of Wastewater Treatment. Glasgow: Strathkelvin Instruments Ltd.

de Godos, I., Arbib, Z., Lara, E., Cano, R., Munoz, R., and Rogalla, F. (2017). "Wastewater treatment in algal systems," in Innovative Wastewater Treatment and Resource Recovery Technologies. Impacts on Energy, Economy and Environment, eds J. M. Lema and S. Suarez (London: IWA Publishing).

de-Bashan, L. E., Moreno, M., Hernandez, J. P., and Bashan, Y. (2002). Removal of ammonium and Phosphorus ions from synthetic wastewater by the microalgae Chlorella vulgaris coimmobilized in alginate beads with microalgae growthpromoting bacterium Azospirillum brasilense. Water Res. 36, 2941-2948. doi: 10.1016/S0043-1354(01)00522-X

Desai, C., Jain, K. R., Boopathy, R., van Hullebusch, E. D., and Madamwar, D. (2021). Editorial: Eco-sustainable bioremediation of textile dye wastewaters: innovative microbial treatment technologies and mechanistic insights of textile dye biodegradation. Front. Microbiol. 12:707083. doi: 10.3389/fmicb.2021. 707083

Dhanker, R., Hussain, T., Tyagi, P., Singh, K. J., and Kamble, S. S. (2021). The emerging trend of bio-engineering approaches for microbial nanomaterial synthesis and its applications. Front. Microbiol. 12:638003. doi: 10.3389/fmicb. 2021.638003

Dhanker, R., Kumar, R., and Hwang, J. S. (2012). Predation by Pseudodiaptomus annandalei (Copepoda: Calanoida) on rotifer prey: size selection, egg predation and effect of algal diet. J. Exp. Mar. Biol. Ecol. 414-415, 44-53. doi: 10.1016/j. jembe.2012.01.011

Dhanker, R., Kumar, R., Tseng, L. C., and Hwang, J. S. (2013). Ciliate (Euplotes sp.) predation by Pseudodiaptomus annandalei (Copepoda: Calanoida) and effects of mono- and pluri-algal diets. Zool. Stud. 52:34. doi: 10.1186/1810-522X-52-34

Fagerstone, K. D., Quinn, J. C., Bradley, T. H., De Long, S. K., and Marchese, A. J. (2011). Quantitative measurement of direct nitrous oxide emissions from microalgae cultivation. Environ. Sci. Technol. 45, 9449-9456. doi: 10.1021/ es202573f

Falkowski, P. G., and Raven, J. A. (2007). Aquatic Photosynthesis, 2nd Edn, Princeton, NJ: Princeton University Press, doi: 10.1515/9781400849727

Gentili, F. G. (2014). Microalgal biomass and lipid production in mixed municipal, dairy, pulp and paper wastewater together with added flue gases. Bioresour. Technol. 169, 23-27. doi: 10.1016/j.biortech.2014.06.061

Gonçalves, A. L., Pires, J. C. M., and Simões, M. (2017). A review on the use of microalgal consortia for wastewater treatment. Algal Res. 24, 403-415. doi: 10.1016/j.algal.2016.11.008

Gouveia, L., Graça, S., Sousa, C., Ambrosano, L., Ribeiro, B., Botrel, E. P., et al. (2016). Microalgae biomass production using wastewater: treatment and costs scale-up considerations. Algal Res. 16, 167-176. doi: 10.1016/j.algal.2016.03.010

Grady, L., Daigger, G., Love, N., and Filipe, C. (2011). Biological Wastewater Treatment, 3rd Edn, Boca Raton, FL: CRC Press, doi: 10.1201/b13775

Grobbelaar, J. U. (1982). Potential of algal production. Water S.A 8, 79-85. doi: 10.1016/0144-4565(90)90079-Y

Grover, J. P. (2000). Resource competition and community structure in aquatic micro-organisms: experimental studies of algae and bacteria along a gradient of organic carbon to inorganic phosphorus supply. Plankton Res. 22, 1591-1610. doi: $10.1093 /$ plankt/22.8.1591

Gudiukaite, R., Nadda, A. K., Gricajeva, A., Shanmugam, S., Nguyen, D. D., and Lam, S. S. (2021). Bioprocesses for the recovery of bioenergy and valueadded products from wastewater: a review. J. Environ. Manage. 300:113831. doi: 10.1016/j.jenvman.2021.113831

Guieysse, B., Plouviez, M., Coilhac, M., and Cazali, L. (2013). Nitrous oxide $\left(\mathrm{N}_{2} \mathrm{O}\right)$ production in axenic Chlorella vulgaris microalgae cultures: evidence, putative pathways, and potential environmental impacts. Biogeoscience 10, 6737-6746. doi: 10.5194/bgd-10-9739-2013

Gunther, S., Trutnau, M., Kleinsteuber, S., Hause, G., Bley, T., Röske, I., et al. (2020). Dynamic of polyphosphate-accumulating bacteria in wastewater treatment plant microbial communities detected via DAPI $\left(4^{\prime}, 6^{\prime}\right.$-Diamidino2-Phenylindole) and tetracycline labeling. Appl. Environ. Microbiol. 75, $2111-$ 2121. doi: 10.1128/AAC.00345-16

Hao, X. D., Wang, Q. L., Zhu, J. Y., and Loosdrecht, M. C. M. V. (2010). Microbiological endogenous processes in biological wastewater treatment systems. Crit. Rev. Environ. Sci. Technol. 40, 239-265. doi: 10.1080/ 10643380802278901

Harleman, D. R. F., and Murcott, S. (1999). The role of physical-chemical wastewater treatment in the megacities of the developing world. Water Sci. Technol. 40, 75-80. doi: 10.5897/AJB

Hellebust, J. A., and Ahmad, I. (1989). Regulation of nitrogen assimilation in green microalgae. Biol. Oceanogr. 6, 241-255. doi: 10.1080/01965581.1988.10749529

Hendriks, A. T. W. M., and Langeveld, G. (2017). Rethinking wastewater treatment plant effluent standards: nutrient reduction or nutrient control. Environ. Sci. Technol. 51, 4735-4737. doi: 10.1021/acs.est.7b01186

Ho, S. H., Chen, W. M., and Chang, J. S. (2010). Scenedesmus obliquus CNW-N as a potential candidate for $\mathrm{CO}_{2}$ mitigation and biodiesel production. Bioresour. Technol. 101, 8725-8730. doi: 10.1016/j.biortech.2010.06.112

Hoh, D., Watson, S., and Kan, E. (2016). Algal biofilm reactors for integrated wastewater treatment and biofuel production: a review. Chem. Eng. J. 287, 466-473. doi: 10.1016/j.cej.2015.11.062

Holger, D., Michael, W. T., and Michael, W. (2006). Wastewater treatment: a model system for microbial ecology. Trends Biotechnol. 24, 483-489. doi: 10.2174/ 1872208313666190924162831

Hussain, J., Wang, X., Sousa, L., Ali, R., Rittmann, B. E., and Liao, W. (2020). Using non-metric multi-dimensional scaling analysis and multi-objective optimization to evaluate green algae for production of proteins, carbohydrates, lipids, and simultaneously fix carbon dioxide. Biomass Bioenergy 141:105711. doi: 10.1016/j.biombioe.2020.105711

Jaishankar, M., Tseten, T., Anbalagan, N., Mathew, B. B., and Beeregowda, K. N. (2014). Toxicity, mechanism and health effects of some heavy metals. Interdiscip. Toxicol. 7, 60-72. doi: 10.2478/intox-2014-0009

Jari, K., Anja, S., and Helvi, H. T. (2003). Elimination of enteric bacteria in biological-chemical wastewater treatment and tertiary filtration units. Water Res. 37, 690-698. doi: 10.1016/s0043-1354(02)00305-6

Jeong, D., and Jang, A. (2020). Exploration of microalgal species for simultaneous water treatment and biofuel production. Environ. Res. 188:109772. doi: 10.1016/ j.envres.2020.109772

Ji, M., Abou-Shanab, R., Hwang, J., Timmes, T., Kim, H., Oh, Y., et al. (2013). Removal of nitrogen and phosphorus from piggery wastewater effluent using the green microalga Scenedesmus obliquus. Environ. Eng. 139, 1198-1205. doi: 10.1061/(ASCE)EE.1943-7870.0000726

Jia, H., and Yuan, Q. (2016). Removal of nitrogen from wastewater using microalgae and microalgae and microalgae consortia. Cogent Environ. Sci. 2:1275089. doi: 10.1080/23311843.2016.1275089

Katam, K., and Bhattacharyya, D. (2021). Improving the performance of activated sludge process with integrated algal biofilm for domestic wastewater treatment: System behavior during the start-up phase. Bioresour. Technol. Rep. 13:100618. doi: 10.1016/j.biteb.2020.100618

Klausmeier, C. A., Litchman, E., Daufresne, T., and Levin, S. A. (2004). Optimal nitrogen-to-phosphorus stoichiometry of phytoplankton. Nature 429, 171-174. doi: 10.1038/nature02454

Kohlheb, N., Affereden, M. V., Lara, E., Arbib, Z., Conthe, M., Poitzsch, C., et al. (2020). Assessing the life-cycle sustainability of algae and bacteria-based wastewater treatment systems: High-rate algae pond and sequencing batch reactor. J. Environ. Manage. 264:110459. doi: 10.1016/j.jenvman.2020.110459 
Kothari, R., Pathak, V. V., Kumar, V., and Singh, D. P. (2012). Experimental study for growth potential of unicellular alga Chlorella pyrenoidosa on dairy wastewater: an integrated approach for treatment and biofuel production. Bioresour. Technol. 116, 466-470. doi: 10.1016/j.biortech.2012.03.121

Krist, V. G., Mark, V. L., Mogens, H., Morten, L., and Sten, B. J. (2004). Activated sludge wastewater treatment plant modelling and simulation: state of the art. Environ. Model. Softw. 19, 763-783. doi: 10.1016/j.envsoft.2003.03.005

Kumar, K. S., Dahms, H. U., Won, E. J., Lee, J. S., and Shin, K. H. (2015). Microalgae - A promising tool for heavy metal remediation. Ecotoxicol. Environ. Saf. 113, 329-352. doi: 10.1016/j.ecoenv.2014.12.019

Larsdotter, K. (2006). Wastewater treatment with microalgae- a literature review. Vatten 62, 31-38.

Latif, M. A., Ghufran, R., Wahid, Z. A., and Ahmad, A. (2011). Integrated application of upflow anaerobic sludge blanket reactor for the treatment of wastewaters. Water Res. 45, 4683-4699. doi: 10.1016/j.watres.2011.05.049

Lee, C. S., Lee, S. A., Ko, S. R., Oh, H. M., and Ahn, C. Y. (2015). Effects of photoperiod on nutrient removal, biomass production, and algalbacterial population dynamics in lab-scale photobioreactors treating municipal wastewater. Water Res. 68, 680-691. doi: 10.1016/j.watres.2014.10.029

Li, G., Bai, X., Li, H., Lu, Z., Zhou, Y., Wang, Y., et al. (2019). Nutrients removal and biomass from anaerobic digested effluent by microalgae: a review. Int. J. Agric. Biol. 12, 8-13. doi: 10.25165/j.ijabe.20191205.3630

Liu, Y., Xu, H. L., Yang, S. F., and Tay, J. H. (2003). Mechanism and models for anaerobic granulation in upflow anaerobic sludge blanket reactor. Water Res. 37, 661-673. doi: 10.1016/S0043-1354(02)00351-2

Louzeiro, N. R., Mavinic, D. S., Oldham, W. K., Meisen, A., and Gardner, I. S. (2002). Methanol induced biological nutrient removal kinetics in a full-scale sequencing batch reactor. Water Res. 36, 2721-2732. doi: 10.1016/S00431354(01)00494-8

Marcin, C., Stobnicka-Kupiec, A., Ławniczek, A. W., Aleksandra, B. K., Małgorzata, G. S., and Rafał, L. F. (2018). Anaerobic bacteria in wastewater treatment plant. Int. Arch. Occup. Environ. Health 91, 571-579. doi: 10.1177/ 1420326X9200100511

Marina, K., Sarah, T., Khalef, R., Shareef, J., Gaby, K., and Racheed, A. (2019). Sources of microplastics pollution in the marine environment: Importance of wastewater treatment plant and coastal landfill. Mar. Pollut. Bull. 146, 608-618.

Mata, T. M., Martins, A. A., and Caetano, N. S. (2010). Microalgae for biodiesel production and other applications: a review. Renew. Sust. Energy Rev. 14, 217-232. doi: 10.1016/j.rser.2009.07.020

Mathew, M. Z., and Alan, H. M. (2009). High quality reuse water by chemicalphysical wastewater treatment. J. Water Contr. Pollut. 42, 437-463. doi: 10. 28991/esj-2019-01187

Mehrabadi, A., Craggs, R., and Farid, M. M. (2015). Wastewater treatment high rate algal ponds (WWTHRAP) for low-cost biofuel production. Bioresour. Technol. 184, 202-214. doi: 10.1016/j.biortech.2014.11.004

Mehrabadi, A., Farid, M. M., and Craggs, R. (2017). Potential of five different isolated colonial algal species for wastewater treatment and biomass energy production. Algal Res. 21, 1-8. doi: 10.1016/j.algal.2016.11.002

Metcalf, E., and Eddy, H. (2003). Wastewater Engineering: Treatment and Reuse, 4th Edn. Columbus: McGraw-Hill Higher Education.

Mohammadi, M., Mowla, D., Esmaeilzadeh, F., and Ghasemi, Y. (2018). Cultivation of microalgae in a power plant wastewater for sulfate removal and biomass production: a batch study. J. Environ. Chem. Eng. 6, 2812-2820. doi: 10.1016/j.jece.2018.04.037

Molazadeh, M., Ahmadzadeh, H., Pourianfar, H. R., Lyon, S., and Rampelotto, P. H. (2019). The use of microalgae for coupling wastewater treatment with $\mathrm{CO}_{2}$ biofixation. Front. Bioeng. Biotechnol. 7:42. doi: 10.3389/fbioe.2019.00042

Morgenroth, E., Kommedal, R., and Harremoes, P. (2002). Processes and modeling of hydrolysis of particulate organic matter in aerobic wastewater treatment - a review. Water Sci. Technol. 45, 25-40. doi: 10.2166/wst.2002.0091

Mostert, E. S., and Grobbelaar, J. U. (1987). The influence of nitrogen and phosphorus on algal growth and quality in outdoor mass algal cultures. Biomass 13, 219-233. doi: 10.1016/0144-4565(87)90061-8

Mulkerrins, D., Dobson, A. D. W., and Colleran, E. (2004). Parameters affecting biological phosphate removal from wastewaters. Environ. Int. 30, 249-259. doi: 10.1016/S0160-4120(03)00177-6

Muñoz, R., and Guieysse, B. (2006). Algal-bacterial processes for the treatment of hazardous contaminants: a review. Water Res. 40, 2799-2815. doi: 10.1016/j. watres.2006.06.011
Nelson, N., and Shem, A. B. (2004). The complex architecture of oxygenic photosynthesis. Nat. Rev. Mol. Cell Biol. 5, 971-982. doi: 10.1038/nrm1525

Ni, S. Q., Ni, J. Y., Hu, D. L., and Sung, S. (2012). Effect of organic matter on the performance of granular anammox process. Bioresour. Technol. 110, 701-705. doi: 10.1016/j.biortech.2012.01.066

Nnaji, C. C. (2014). A review of the upflow anaerobic sludge blanket reactor. Desalin. Water Treat. 52, 4122-4143. doi: 10.1080/19443994.2013.80 0809

Ogbonna, J. C., Yoshizawa, H., and Tanaka, H. (2000). Treatment of high strength organic wastewater by a mixed culture of photosynthetic microorganisms. J. Appl. Phycol. 12, 277-284. doi: 10.1023/A:1008188311681

Ødegaard, H., and Karlsson, I. (1994). "Chemical wastewater treatment - value for money," in Chemical Water and Wastewater Treatment III, eds R. Klute and H. H. Hahn (Berlin: Springer). doi: 10.1007/978-3-642-79110-9_14

Paddock, M. (2019). Microalgae wastewater treatment: a brief history. [Preprints]. doi: 10.20944/preprints201912.0377.v1

Park, J. B. K., and Craggs, R. J. (2011). Nutrient removal in wastewater treatment high rate algal ponds with carbon dioxide addition. Water Sci. Technol. 63, 1758-1764. doi: 10.2166/wst.2011.114

Park, J. B. K., Craggs, R. J., and Shilton, A. N. (2011). Wastewater treatment high rate algal ponds for biofuel production. Biresour. Technol. 102, 35-42. doi: 10.1016/j.biortech.2010.06.158

Pogue, A. J., and Gilbride, K. A. (2007). Impact of protozoan grazing on nitrification and the ammonia- and nitrate- oxidising bacterial communities in activated sludge. Can. J. Microbiol. 53, 559-571. doi: 10.1139/w07-027

Pollard, P. C., and Greenfield, P. F. (1997). Measuring in situ specific bacterial growth rates and population dynamics in wastewater. Water Res. 31, 1074-1082. doi: 10.1016/S0043-1354(96)00326-0

Prandini, J. M., da Silva, M. L. B., Mezzari, M. P., Pirolli, M., Michelon, W., and Soares, H. M. (2016). Enhancement of nutrient removal from swine wastewater digestate coupled to biogas purification by microalgae Scenedesmus spp. Bioresour. Technol. 202, 67-75. doi: 10.1016/j.biortech.2015.11.082

Rajta, A., Bhatia, R., Setia, H., and Pathania, P. (2020). Role of heterotrophic aerobic denitrifying bacteria in nitrate removal from wastewater. J. Appl. Microbiol. 128, 1261-1278. doi: 10.1111/jam.14476

Ramos Tercero, E. A., Sforza, E., Morandini, M., and Bertucco, A. (2014). Cultivation of Chlorella protothecoides with urban wastewater in continuous photobioreactor: biomass productivity and nutrient removal. Appl. Biochem. Biotechnol. 172, 1470-1485. doi: 10.1007/s12010-013-0629-9

Raouf, N. A., Homaidan, A. A. A., and Ibraheem, I. B. M. (2012). Microalgae and wastewater treatment. Saudi J. Biol. Sci. 19, 257-275. doi: 10.1016/j.sjbs.2012. 04.005

Richard, D. C. (2019). Ecological assessment of the upper river. J. Oreohelix Ecol. 234, 12-23. doi: 10.1093/mollus/eym006

Rickard, L. F., and McClintock, S. A. (1992). Potassium and magnesium requirements for enhanced biological phosphorus removal from wastewater. Water Sci. Technol. 26, 2203-2206. doi: 10.2166/wst.1992.0697

Ruiz, J., Álvarez-Díaz, P. D., Arbib, Z., Garrido-Pérez, C., Barragán, J., and Perales, J. A. (2013). Performance of a flat panel reactor in the continuous culture of microalgae in urban wastewater: prediction from a batch experiment. Bioresour. Technol. 127, 456-463. doi: 10.1016/j.biortech.2012.09.103

Salces, B. M., Riano, B., Hernandez, D., and Gonzalez, M. C. G. (2019). "Microalgae and wastewater treatment: advantages and disadvantages," in Microalgae Biotechnology for Development of Biofuel and Wastewater Treatment, eds M. Alam and Z. Wang (Singapore: Springer), doi: 10.1007/978-981-13-2264-8_20

Schumacher, G., Blume, T., and Sekoulov, I. (2003). Bacteria reduction and nutrient removal in small wastewater treatment plants by an algal biofilm. Water Sci. Technol. 47, 195-202. doi: 10.2166/wst.2003.0605

Shekh, A. Y., Shrivastava, P., Krishnamurthi, K., Mudliar, S. N., Devi, S. S., Kanade, G. S., et al. (2016). Stress enhances poly-unsaturation rich lipid accumulation in Chlorella sp. and Chlamydomonas sp. Biomass Bioenergy 84, 59-66. doi: 10.1016/j.biombioe.2015.11.013

Singh, B., Bauddh, K., and Bux, F. (2015). Algae and Environmental Sustainability, 1st Edn, Cham: Springer.

Singh, S. P., and Singh, P. (2014). Effect of $\mathrm{CO}_{2}$ concentration on algal growth: a review. Renew. Sust. Energ. Rev. 38, 172-179. doi: 10.1016/j.rser.2014.05.043

Singh, S. P., and Singh, P. (2015). Effect of temperature and light on the growth of algae species: a review. Renew. Sust. Energ. Rev. 50, 431-444. doi: 10.1016/j.rser. 2015.05.024 
Sousa, C. F. E. (2013). Oxygen Accumulation in Photobioreactors. Wageningen: Wageningen University.

Sturm, B. S. M., and Lamer, S. L. (2011). An energy evaluation of coupling nutrient removal from wastewater with algal biomass production. Appl. Energy 88, 3499-3506. doi: 10.1016/j.apenergy.2010.12.056

Su, Y. (2021). Revisiting carbon, nitrogen and, phosphorus metabolisms in microalgae for wastewater treatment. Sci. Total Environ. 768:144590. doi: 10. 1016/j.scitotenv.2020.144590

Su, Y., Mennerich, A., and Urban, B. (2011). Municipal wastewater treatment and biomass accumulation with a wastewater-born and settleable algalbacterial culture. Water Res. 45, 3351-3358. doi: 10.1016/j.watres.2011.03. 046

Sutherland, D. L., Turnbull, M. H., and Craggs, R. J. (2014). Increased pond depth improves algal productivity and nutrient removal in wastewater treatment high rate algal ponds. Water Res. 53, 271-281. doi: 10.1016/j.watres.2014.01.025

Tong, R. M., Beck, M. B., and Latten, A. (1980). Fuzzy control of the activated sludge wastewater treatment process. Automatica 16, 675-701.

Ugwu, C. U., Aoyagi, H., and Uchiyama, H. (2007). Influence of irradiance, dissolved oxygen concentration, and temperature on the growth of Chlorella sorokiniana. Photosynthetica 45, 309-311. doi: 10.1007/s11099-007-0052-y

Wagner, M., and Loy, A. (2002). Bacterial community composition and function in sewage treatment systems. Curr. Opin. Biotechnol. 13, 218-227. doi: 10.1016/ S0958-1669(02)00315-4

Wang, L., Min, M., Li, Y., Chen, P., Chen, Y., Liu, Y., et al. (2010). Cultivation of green algae Chlorella sp. in different wastewaters from municipal wastewater treatment plant. Appl. Biochem. Biotechnol. 162, 1174-1186. doi: 10.1007/ s12010-009-8866-7

Williams, P. J. B., and Laurens, L. M. L. (2010). Microalgae as biodiesel and biomass feedstocks: review \& analysis of the biochemistry, energetics and economics. Energy Environ. Sci. 3:554. doi: 10.1039/B924978H

Wollmann, F., Ackermann, S. D. J. U., Bley, T., Walther, T., Steingroewer, J., and Krujatz, F. (2019). Microalgae wastewater treatment: biological and technological approaches. Eng. Life Sci. 19, 860-871. doi: 10.1002/elsc. 201900071

Xin, L., Hong-ying, H., Ke, G., and Jia, Y. (2010). Growth and nutrient removal properties of a freshwater microalga Scenedesmus sp. LX1 under different kinds of nitrogen sources. Ecol. Eng. 36, 379-381. doi: 10.1016/j.ecoleng.2009.11.003

Young, P., Taylor, M., and Fallowfield, H. J. (2017). Mini-review: high rate algal ponds, flexible systems for sustainable wastewater treatment. World J. Microbiol. Biotechnol. 33:117. doi: 10.1007/s11274-017-2282-x

Yuansong, W., Renze, R. V. H., Arjan, R. B., Dick, H. E., and Yaobo, F. (2003). Minimization of excess sludge production for biological wastewater treatment. Water Res. 27, 4453-4467. doi: 10.1016/S0043-1354(03)00441-X

Zahara, A., Dahms, H.-U., Mika, S., Eduardo, H. E., and Roberto, P. (2020). Effectiveness of wastewater treatment systems in removing microbial agents: a systematic review. Global. Health 12, 2-10. doi: 10.1080/17441692.2016. 1273370

Conflict of Interest: The authors declare that the research was conducted in the absence of any commercial or financial relationships that could be construed as a potential conflict of interest.

Publisher's Note: All claims expressed in this article are solely those of the authors and do not necessarily represent those of their affiliated organizations, or those of the publisher, the editors and the reviewers. Any product that may be evaluated in this article, or claim that may be made by its manufacturer, is not guaranteed or endorsed by the publisher.

Copyright (C) 2022 Mathew, Khatana, Vats, Dhanker, Kumar, Dahms and Hwang. This is an open-access article distributed under the terms of the Creative Commons Attribution License (CC BY). The use, distribution or reproduction in other forums is permitted, provided the original author(s) and the copyright owner(s) are credited and that the original publication in this journal is cited, in accordance with accepted academic practice. No use, distribution or reproduction is permitted which does not comply with these terms. 